\title{
Prenylindole Alkaloids from Raputia praetermissa (Rutaceae) and their Chemosystematic Significance
}

\author{
Lisandra V. Rosas, Thiago André M. Veiga, João B. Fernandes, \\ Paulo C. Vieira and M. Fátima das G. F. da Silva* \\ Departamento de Química, Universidade Federal de São Carlos, \\ CP 676, 13565-905 São Carlos-SP, Brazil
}

\begin{abstract}
O extrato diclorometano do caule de Raputia praetermissa levou ao isolamento de quatro compostos novos, 4-desóxi-raputindol C (1), raputimonoindol A-B $(\mathbf{2}, \mathbf{3})$ e hexadecanil 2-hidróxi4-metóxi-cinnamato (5), juntamente com os alcalóides 5-(4-metóxi-metilfuran-2-il)-1 $H$-indol (raputimonoindol C), furoquinolinos maculosidine, robustine, evolitrine e dictamnine. O estudo do extrato hexano levou ao isolamento de $N$-metil-4-metóxi-quinolin-2(1H)-ona, skimmianina, cicloartenona, sitosterol, stigmasterol e sitostenona. Os alcalóides antranílicos isolados indicam que o gênero possui afinidade química relevante com aqueles da tribo Cusparieae, mas difere de Neoraputia devido à ausência de alcalóides prenilindois neste último, cujas espécies foram anteriormente incluídas em Raputia.
\end{abstract}

The dichloromethane extract from the stems of Raputia praetermissa afforded four new compounds, 4-deoxyraputindole C (1), raputimonoindole A-B $(\mathbf{2}, \mathbf{3})$, and hexadecanyl 2-hydroxy4-methoxy-cinnamate (5), besides the alkaloids 5-(4-methoxymethylfuran-2-yl)-1H-indole (raputimonoindole $\mathrm{C}$ ), furoquinolines maculosidine, robustine, evolitrine and dictamnine. The hexane extract yielded $\mathrm{N}$-methyl-4-methoxyquinolin-2(1H)-one, skimmianine, cycloartenone, sitosterol, stigmasterol and sitostenone. The anthranilate alkaloid content indicates that the genus is strongly related to those included in Cusparieae tribe, but differs from Neoraputia by the absence of prenylindole alkaloids in the late, whose species have previously been placed in Raputia.

Keywords: Raputia praetermissa, Neoraputia, Rutaceae, prenylindole alkaloids, chemosystematics

\section{Introduction}

The Raputia genus was established by Aublet in $1775,{ }^{1}$ and based on morphological characteristics of $R$. aromatica Aubl. Emmerich later dismembered this genus, ${ }^{1}$ placing most of the species into Neoraputia Emmerich, Sigmatanthus Huber ex Emmerich, and Raputiarana Emmerich. Following the research of Kallunki and Pirani, ${ }^{2-5}$ a total of eleven species have now been included in the Raputia genus: $R$. aromatica Aubl., $R$. maroana (R. S. Cowan) Kallunki, R. neblinensis (R. S. Cowan) Kallunki, R. ulei (K. Krause) Kallunki, R. brevipedunculata Kallunki, $R$. megalantha Kallunki, R. simulans Kallunki, R. amazonica (Huber) Kallunki (synonym: Ravenia amazonica Huber), R. szczerbanii (Steyerm.) Kallunki (synonym: Lubaria szczerbanii Steyerm.), R. hirsuta (Gereau) Kallunki and

*e-mail: dmfs@power.ufscar.br
R. praetermissa Pirani \& Kallunki. Raputia and Neoraputia are assigned to the tribe Cusparieae and are distributed from Venezuela and French Guiana to Amazonian Colombia, Peru and Brazil. ${ }^{5}$

Previous investigations of Neoraputia reported the presence of eleven polymethoxylated flavonoids, six flavones, three 5,6-(2",2"-dimethylpyrano)flavones, one 6,7-(2",2"-dimethylpyrano)flavone and one flavanone from N. alba (Engler) Emmerich;, five polymethoxylated flavones and two flavanones, 2'-hydroxy-3,4,4',5,6'pentamethoxychalcone, three 5',6'-(2",2"'-dimethylpyrano)polymethoxylated chalcones from $N$. magnifica var. magnifica (Engler) Emmerich; ${ }^{8,9}$ ten polymethoxylated flavonoids, six flavones, three 6,7-(2",2"-dimethylpyrano) flavones and one 6-(3"-hydroxy,3"-methyl-trans-but-1"enyl)flavone from $N$. paraensis. ${ }^{10,11}$ A reinvestigation of $N$. paraensis searching for alkaloids afforded flindersine, skimmianine, 8-methoxyflindersine and dictamnine. ${ }^{12}$ 
C-glycosylflavones were also reported from $N$. paraensis, ${ }^{13}$ which was cited as Raputia paraensis, but this species was transferred to Neoraputia by Emmerich. ${ }^{1}$

The first investigation about the chemistry of Raputia reported the presence of cyclopentyl bisindole alkaloids raputiindoles A-D from $R$. simulans Kllunki. ${ }^{14}$

In this paper we report a phytochemical study on R. praetermissa Pirani \& Kallunki, and the chemosystematic significance of isolated compounds is discussed in order to clarify the relationships between Raputia and Neoraputia.

\section{Results and Discussion}

The dichloromethane extract from the stems of Raputia praetermissa afforded four prenylindole alkaloids (1-4), a cinnamic acid derivative (5) (Figure 1), and furoquinoline alkaloids maculosidine, robustine, evolitrine ${ }^{15}$ and dictamnine. ${ }^{16}$ The hexane extract yielded $\mathrm{N}$-methyl-4-methoxyquinolin-2(1H)-one, ${ }^{17}$ skimmianine, ${ }^{17}$ cycloartenone,${ }^{18}$ sitosterol, stigmasterol and sitostenone.

Compound 1, $\mathrm{C}_{26} \mathrm{H}_{26} \mathrm{~N}_{2}$ (HREIMS), was identified as a bisindole alkaloid. The presence of two indole nucleus was suggested by an UV absorption maximum at $328 \mathrm{~nm}$, an IR band at $3426 \mathrm{~cm}^{-1}(\mathrm{NH})$, and ${ }^{1} \mathrm{H}$ NMR signals for N-H protons at $\delta 8.00$ and 8.04 (brs, no correlation in the HSQC spectrum) (Table 1), which in the COSY experiments showed cross peaks with the ${ }^{1} \mathrm{H}$ signals at $\delta_{\mathrm{H}} 7.14(\mathrm{dd}, 3.2$, $2.5 \mathrm{~Hz}$ ), 6.50 (ddd, 3.2, 2.5, $1.0 \mathrm{~Hz}$ ), 7.11 (dd, 3.0, 2.5 Hz) and $6.44(\mathrm{ddd}, 3.0,2.5,1.0 \mathrm{~Hz})$, respectively. These signals were then assigned to $2 \mathrm{~N}-\mathrm{H}(\delta 8.00$ and 8.04$), 2 \mathrm{H}-\alpha\left(\delta_{\mathrm{H}}\right.$ 7.14 and 7.11) and $2 \mathrm{H}-\beta\left(\delta_{\mathrm{H}} 6.50\right.$ and 6.44$)$ of the indole rings, respectively. $\mathrm{HMBC}$ cross peaks (Figure 2 ) between the signals H-4' $\left(\delta_{\mathrm{H}} 7.30\right) / \mathrm{C}-3^{\prime}\left(\delta_{\mathrm{C}} 102.3\right), \mathrm{C}-6$ ' $\left(\delta_{\mathrm{C}} 144.3\right)$, 7'a $\left(\delta_{\mathrm{C}} 135.5\right)$ and $40.7(\mathrm{CH})$; H-7' $\left(\delta_{\mathrm{H}} 7.18\right) / \mathrm{C}-3$ ' a $\left(\delta_{\mathrm{C}}\right.$ $127.3), \mathrm{C}-5$ ' $\left(\delta_{\mathrm{C}} 139.4\right)$, and $\delta_{\mathrm{C}} 48.5$ (quaternary carbon) led to the assignment of a $5^{\prime}, 6^{\prime}$-dialkylindole system. Moreover, the observed cross peaks between the ${ }^{1} \mathrm{H}$ signals at $\delta_{\mathrm{H}} 4.07(\mathrm{H}-6), 2.43(\mathrm{H}-5 \mathrm{a})$ and $1.81(\mathrm{H}-5 \mathrm{~b})$, and the ${ }^{13} \mathrm{C}$ signals for C-5', C-6' and 48.5 (quaternary carbon, C-3) suggested a 3,3,6-trisubstituted cyclopentyl fused to the indole ring at C-5' and C-6'. An isobutene group was identified from the ${ }^{1} \mathrm{H}$ NMR signals at $\delta_{\mathrm{H}} 5.22$ (dsep, 9.0, 1.0), 1.82 (br s, 3H), and 1.79 (br s, 3H), assigned to olefinic proton and methyl groups, respectively. This was supported by the HMBC experiments which showed correlations from the olefinic proton at $\delta_{\mathrm{H}} 5.22$ to the methyl carbons at $\delta_{\mathrm{c}}$ 25.9 and 18.3. The isobutene group was connected at C-6 due to coupling of $\mathrm{H}-6$ to the olefinic proton at $\delta_{\mathrm{H}} 5.22$. A methyl group must be connected at $\mathrm{C}-3$ due to the observed $\mathrm{HMBC}$ cross peaks between its ${ }^{1} \mathrm{H}$ signal at $\delta_{3 \mathrm{H}} 1.59$ and the ${ }^{13} \mathrm{C}$ signals for $\mathrm{C}-6$ ' and $\mathrm{C}-3$. This structural unit was corroborated by the MS base-peak at $\mathrm{m} / \mathrm{z} 223.13387$ $(100.0 \%)$ resulting from C-3-C-2 cleavage.

The ${ }^{1} \mathrm{H}$ NMR spectrum also showed signals for three hydrogens with ortho and meta coupling constants, $\delta_{\mathrm{H}}$ $7.50(\mathrm{~d}, 0.7 \mathrm{~Hz}), 7.23(\mathrm{dd}, 8.4,0.7 \mathrm{~Hz})$ and $7.22(\mathrm{~d}$, $8.4 \mathrm{~Hz}$ ), suggesting the second indole nucleus to be monosubstituted. In adition, the presence of a transdisubstituted double bond was evidenced by two vinylic protons at $\delta_{\mathrm{H}} 6.13\left(\delta_{\mathrm{C}} 126.8\right)$ and $6.40\left(\mathrm{~d}, 16.0 \mathrm{~Hz} ; \delta_{\mathrm{C}} 136.0\right)$ with a vicinal coupling constant of $16.0 \mathrm{~Hz}$. From HMBC experiments the observed cross peak between the signal with meta coupling constant at $\delta_{\mathrm{H}} 7.50$ and the ${ }^{13} \mathrm{C}$ signal for C-3" $\left(\delta_{\mathrm{C}} 102.7\right)$, permited the assignment of the signal at $\delta_{\mathrm{H}} 7.50$ to H-4" (C-4", $\left.\delta_{\mathrm{C}} 118.7\right)$. The meta coupling constant for H-4" indicated that C-5" was substituted. The

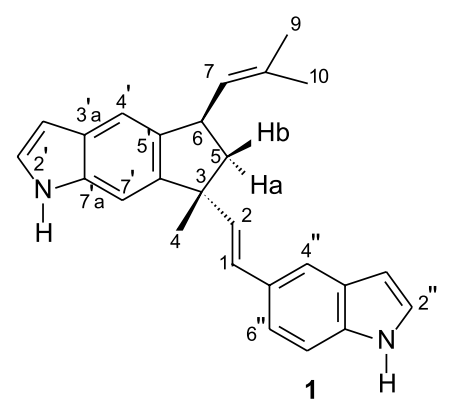<smiles>C=CC=CC1C(=O)COC1c1ccc2[nH]ccc2c1</smiles>
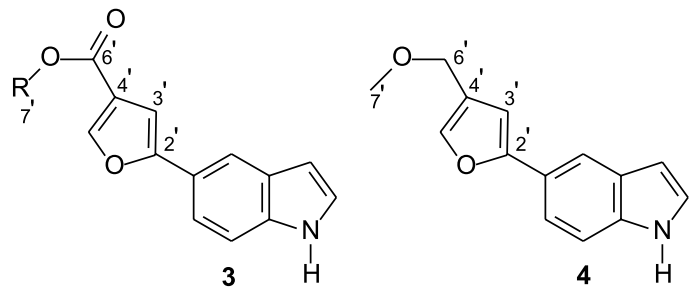<smiles>COc1ccc(C=CC(=O)OC(C)C)c(O)c1</smiles>

Figure 1. Compounds isolated from Raputia praetermissa. 
Table 1. ${ }^{1} \mathrm{H}$ NMR data for $1-4$

\begin{tabular}{|c|c|c|c|c|c|}
\hline $\mathrm{H}$ & 1 & $\mathrm{H}$ & 2 & 3 & 4 \\
\hline 1 ' & 8.00 br s & & & & \\
\hline $2^{\prime}$ & $7.14 \mathrm{dd}(3.2,2.5)$ & & & & \\
\hline 3' & 6.50 ddd $(3.3,2.5,1.0)$ & & & & \\
\hline 4' & $7.30 \mathrm{~s}$ & & & & \\
\hline 7' & $7.18 \mathrm{~s}$ & 2 & $4.64 \mathrm{~d}(5.6)$ & & \\
\hline 1 & $6.13 \mathrm{~d}(16.0)$ & $3{ }^{\prime}$ & $2.73 \operatorname{td}(7.0,5.6)$ & $6.88 \mathrm{~s}$ & $6.65 \mathrm{~s}$ \\
\hline 2 & $6.40 \mathrm{~d}(16.0)$ & 5 'a & $4.44 \mathrm{dd}(13.1,2.3)$ & $8.04 \mathrm{~s}$ & $7.46 \mathrm{~s}$ \\
\hline 4 & $1.59 \mathrm{~s}$ & 5 'b & $4.65 \mathrm{dd}(13.1,2.3)$ & & \\
\hline $5 \mathrm{a}$ & $2.43 \mathrm{dd}(12.1,6.8)$ & 6'a & $4.99 \mathrm{~d}(2.3)$ & & $4.11 \mathrm{~s}$ \\
\hline $5 b$ & $1.81 \mathrm{dm}(12.1)$ & $6 ’ b$ & $4.97 \mathrm{~d}(2.3)$ & & \\
\hline 6 & $4.07 \mathrm{dm}(9.0)$ & $7^{\prime}$ & 2.28 br t (7.0) & $3.87 \mathrm{~s}$ & $3.44 \mathrm{~s}$ \\
\hline 7 & 5.22 dsep $(9.0,1.0)$ & 8 & 5.12 tsep $(7.0,1.2)$ & & \\
\hline 9 & $1.82 \mathrm{br} \mathrm{s}$ & $10^{\prime}$ & $1.64 \mathrm{br} \mathrm{s}$ & & \\
\hline 10 & $1.79 \mathrm{br} \mathrm{s}$ & $11^{\prime}$ & $1.60 \mathrm{br} \mathrm{s}$ & & \\
\hline $1 "$ & 8.04 br s & 1 & 8.15 br s & 9.85 br s & 8.35 br s \\
\hline $2 ”$ & $7.11 \mathrm{dd}(3.0,2.5)$ & 2 & $7.19 \mathrm{~d}(3.1,1.6)$ & $7.25 \mathrm{dd}(2.0,1.2)$ & $7.14 \mathrm{t}(2.4)$ \\
\hline 3" & 6.44 ddd $(3.0,2.5,1.0)$ & 3 & $6.53 \mathrm{~m}$ & 6.55 br t (2.0) & $6.58 \mathrm{~m}$ \\
\hline $4 "$ & $7.50 \mathrm{~d}(0.7)$ & 4 & $7.60 \mathrm{~d}(0.8)$ & 7.97 br s & 8.00 br s \\
\hline $6 "$ & $7.23 \mathrm{dd}(8.4,0.7)$ & 6 & $7.20 \mathrm{dd}(8.5,2.0)$ & $7.50 \mathrm{dd}(8.5,1.6)$ & $7.53 \mathrm{dd}(8.4,1.8)$ \\
\hline 7" & $7.22 \mathrm{~d}(8.4)$ & 7 & $7.37 \mathrm{~d}(8.5)$ & $7.43 \mathrm{~d}(8.5)$ & $7.33 \mathrm{~d}(8.4)$ \\
\hline
\end{tabular}

${ }^{1} \mathrm{H}$ NMR spectrum was acquired in $\mathrm{CDCl}_{3}$ at $400 \mathrm{MHz}$. TMS was used as internal standard. Chemical shifts are shown in the $\delta$ scale with $J$ values (Hz) in parentheses.

attachment of the ethylenyl bridge to C-3 and C-5" was evidenced from HMBC correlations $\mathrm{H}-1\left(\delta_{\mathrm{H}} 6.13\right) / \mathrm{C}-3$, C-4" ' and H-2 ( $\left.\delta_{\mathrm{H}} 6.40\right) / \mathrm{C}-3$, C-6'. These spectral characteristics are in agreement with those published for raputindole C (6, Figure 3), isolated from Raputia simulans. ${ }^{14}$ The main difference observed in the ${ }^{1} \mathrm{H}$ and ${ }^{13} \mathrm{C}$ NMR spectra (Tables 1 and 2 ) of compound $\mathbf{1}$, when compared to those of $\mathbf{6}$, was the replacement of the signal for an oxymethylene by a methyl singlet $\left(\mathrm{C}-4, \delta_{3 \mathrm{H}} 1.59, \delta_{\mathrm{C}} 27.1\right)$. The relative stereochemistry of compound $\mathbf{1}$, named as 4-deoxyraputindole $\mathrm{C}$, was determined from gNOESY experiments. The nOes of $\mathrm{H}-2, \mathrm{H}-1$, and $\mathrm{H}-5 \mathrm{a}$, coming from $\mathrm{H}-6$, indicated that $\mathrm{H}-6$ and the ethylenylindole system are on the same side of the five-membered ring, whereas nOe between $\mathrm{H}-5 \mathrm{~b}$ and $\mathrm{CH}_{3}-4$, required the methyl group to be anti $(\beta)$ to $\mathrm{H}-6$, and syn to the isobutene chain.

Compounds 2-4 showed the spectral characteristic of a 5 -substituted- $1 H$-indole alkaloid (Tables 1,2 ). The ${ }^{13} \mathrm{C}$ NMR spectrum (Table 2) revealed resonances for $\mathrm{C}-2$ to $\mathrm{C}-7 \mathrm{a}$ in close agreement with those for the corresponding carbons in the structural unit 5-substituted- $1 \mathrm{H}$-indole of compound 1, except for C-5 whose chemical shift was affected by a different substituent. Elemental analysis and
MS indicated the molecular formula to be $\mathrm{C}_{18} \mathrm{H}_{21} \mathrm{NO}$ for compound 2, requiring the presence of an aliphatic chain of 10 carbons and one oxygen. A heterocyclic oxolane was identified from the ${ }^{1} \mathrm{H}$ NMR spectrum, which showed a proton at $\delta_{\mathrm{H}} 2.73\left(\mathrm{td}, 7.0,5.6, \mathrm{H}-3^{\prime} ; \delta_{\mathrm{C}} 51.6\right)$ coupled to a proton attached to carbon adjacent to an oxygen atom $\left(\delta_{\mathrm{H}}\right.$ 4.64, d, 5.6, H-2'; $\delta_{\mathrm{C}} 86.6$ ), and two doublet of doublets for an oxymethylene $\left(\delta_{\mathrm{H}} 4.44,4.65, J 13.1,2.3,2 \mathrm{H}-5\right.$ '; $\delta_{\mathrm{C}}$ 71.5). Observed HMBC cross peaks between the ${ }^{1} \mathrm{H}$ signals at $\delta_{\mathrm{H}} 2.73\left(\mathrm{H}^{\prime} 3^{\prime}\right)$ and $4.64\left(\mathrm{H}-2^{\prime}\right)$ with the ${ }^{13} \mathrm{C}$ signals at $\delta_{\mathrm{C}} 132.7(\mathrm{C}-5)$ and $119.1(\mathrm{C}-4)$, respectively, as well as those of H-5'a and H-5'b $\left(\delta_{\mathrm{H}} 4.44\right.$ and 4.65$)$ with $\mathrm{C}-3$ ' $\left(\delta_{\mathrm{C}} 51.6\right)$, suggested the attachment of the heterocyclic oxolane to $\mathrm{C}-5$ of the indole nucleus. The presence of an isopentene group was deduced from the proton resonances at $\delta_{\mathrm{H}} 5.12$ (tsep, 7.0, 1.2, H-8'), 1.64 (br s, 3H-10'), 1.60 (br s, 3H-11'), 2.28 (br t, 7.0, 2H-7'), and corroborated by the HMBC correlation between the methyl and methylene protons with the olefinic carbons at $\delta_{\mathrm{C}} 132.7$ (C-9') and 121.7 (C-8'). This was supported by the mass spectrum which showed fragment at $m / z 211\left[\mathrm{C}_{18} \mathrm{H}_{21} \mathrm{NO}-\mathrm{C}_{4} \mathrm{H}_{8}\right]^{*}$. The ${ }^{1} \mathrm{H}-{ }^{1} \mathrm{H}$ coupling between the methylene at $\delta_{\mathrm{H}} 2.28$ and $\mathrm{H}-3^{\prime}\left(\delta_{\mathrm{H}} 2.73\right)$ indicated the linkage of the isopentene chain to C-3'. An exomethylene $\left(\delta_{\mathrm{H}} 4.99,4.97, J 2.3,2 \mathrm{H}-6\right.$ '; 

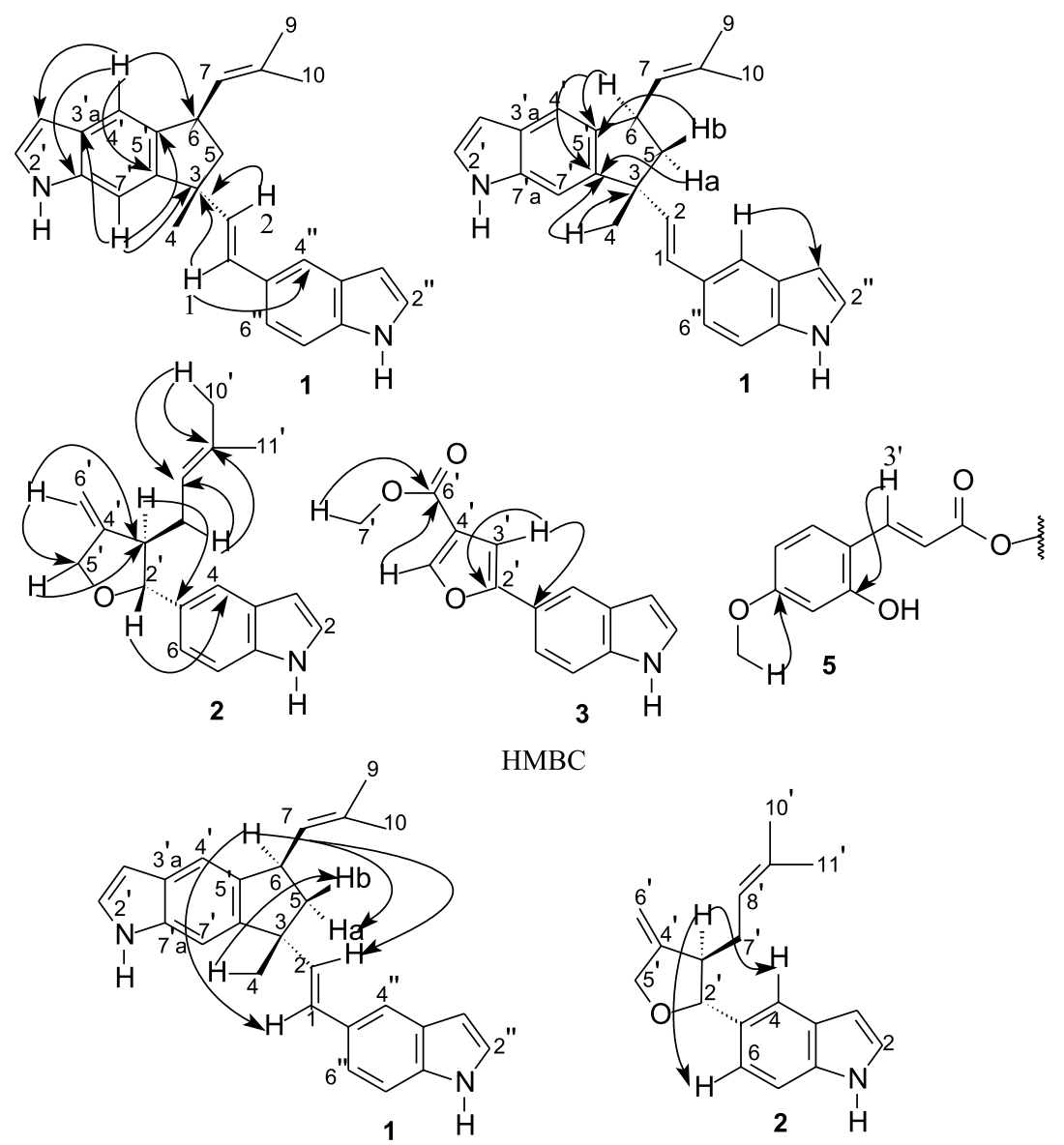

HMBC

$3 \stackrel{\mathrm{H}}{\mathrm{H}}$

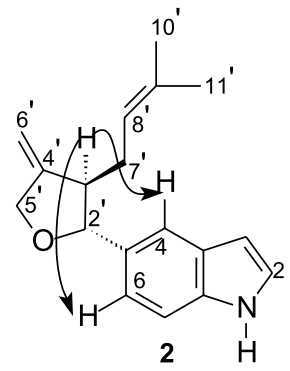

NOESY

Figure 2. Relevant HMBC and NOESY interactions observed for compounds 1-3 and $\mathbf{5}$.
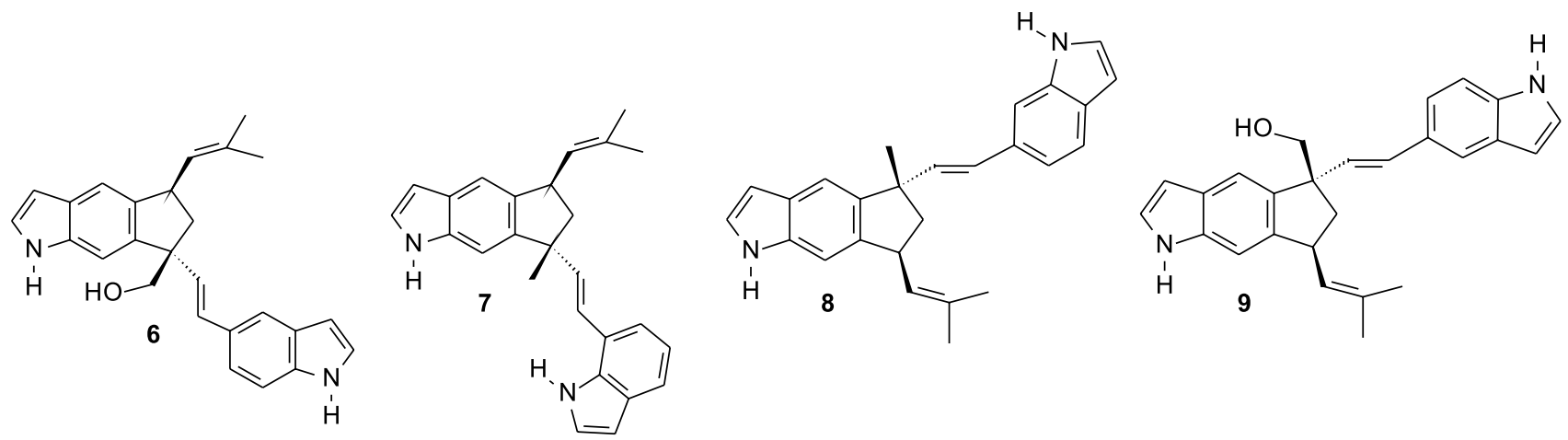

Figure 3. Raputindoles A (8), B (7), C (6) and D (9) isolated from Raputia simulans.

$\delta_{\mathrm{C}}$ 103.6) must be connected at C-4' of oxolane ring on the basis of the observed cross peaks between the ${ }^{1} \mathrm{H}$ signals at $\delta_{2 \mathrm{H}} 4.99 / 4.97$ and the ${ }^{13} \mathrm{C}$ signals for C-3' $\left(\delta_{\mathrm{C}} 51.6\right)$ and C-5' $\left(\delta_{\mathrm{C}} 71.5\right)$. As for compound $\mathbf{1}$, the relative stereochemistry of $\mathbf{2}$ was deduced from gNOESY experiments. The nOes of the H-4 and H-6, coming from H-3', indicated that H-3' and the indole system must be on the same side of the oxolane ring. The above data confirmed the structure of $\mathbf{2}$, here named as raputimonoindole $\mathrm{A}$.
As commented above compounds 2-4 showed the spectral characteristic of a 5 -substituted- $1 H$-indole alkaloid. Elemental analysis and MS indicated the molecular formula to be $\mathrm{C}_{14} \mathrm{H}_{11} \mathrm{NO}_{3}$ and $\mathrm{C}_{14} \mathrm{H}_{13} \mathrm{NO}_{2}$ for compounds $\mathbf{3}$ and $\mathbf{4}$, respectively, requiring the presence of an aliphatic chain of 6 carbons $\left(\mathrm{C}_{6} \mathrm{H}_{5} \mathrm{O}_{3}\right.$ and $\mathrm{C}_{6} \mathrm{H}_{7} \mathrm{O}_{2}$, respectively) and indole nucleus $\left(\mathrm{C}_{8} \mathrm{H}_{6} \mathrm{~N}\right)$. Their ${ }^{1} \mathrm{H}$ NMR resonances, when compared to those of $\mathbf{2}$, showed low field shifts for the disubstituted furan ring potons. In 
Table 2. ${ }^{13} \mathrm{C}$ NMR data for $\mathbf{1 - 4}$, and 6

\begin{tabular}{|c|c|c|c|c|c|c|}
\hline $\mathrm{C}$ & 1 & $6^{14}$ & $\mathrm{C}$ & 2 & 3 & 4 \\
\hline $2^{\prime}$ & 123.8 & 124.1 & & & & \\
\hline 3, & 102.3 & 102.4 & & & & \\
\hline 3'a & 127.3 & 128.0 & & & & \\
\hline $4^{\prime}$ & 115.4 & 116.0 & & & & \\
\hline 5 & 139.4 & 140.3 & & & & \\
\hline $6^{\prime}$ & 144.3 & 139.8 & & & & \\
\hline $7^{\prime}$ & 105.8 & 106.2 & & & & \\
\hline 7'a & 135.5 & 135.5 & & & & \\
\hline 1 & 126.8 & 131.1 & $2^{\prime}$ & 86.6 & 156.0 & 156.1 \\
\hline 2 & 136.0 & 131.2 & 3 & 51.6 & 102.3 & 103.7 \\
\hline 3 & 48.5 & 55.1 & $4^{\prime}$ & 152.1 & 121.0 & 123.8 \\
\hline 4 & 27.1 & 68.9 & 5 & 71.5 & 146.3 & 139.2 \\
\hline 5 & 50.0 & 43.9 & $6^{\prime}$ & 103.6 & 165.0 & 66.0 \\
\hline 6 & 40.7 & 40.6 & $7^{\prime}$ & 29.0 & 51.8 & 57.6 \\
\hline 7 & 128.5 & 128.3 & $8^{\prime}$ & 121.7 & & \\
\hline 8 & 132.4 & 132.7 & $9^{\prime}$ & 132.7 & & \\
\hline 9 & 25.9 & 25.9 & $10^{\prime}$ & 18.1 & & \\
\hline 10 & 18.3 & 18.3 & $11^{\prime}$ & 25.7 & & \\
\hline 2" & 124.4 & 123.9 & 2 & 124.4 & 125.5 & 124.9 \\
\hline 3" & 102.7 & 102.9 & 3 & 102.8 & 102.4 & 102.8 \\
\hline 3 "a & 127.3 & 128.1 & $3 a$ & 127.7 & 128.0 & 127.9 \\
\hline 4" & 118.7 & 119.0 & 4 & 119.1 & 116.6 & 116.1 \\
\hline $5 "$ & 129.8 & 129.3 & 5 & 132.7 & 123.0 & 123.0 \\
\hline 6" & 120.4 & 120.5 & 6 & 121.0 & 118.6 & 118.7 \\
\hline 7" & 110.9 & 111.0 & 7 & 110.9 & 111.7 & 111.2 \\
\hline 7"a & 135.1 & 135.4 & $7 \mathrm{a}$ & 135.5 & 136.0 & 135.3 \\
\hline
\end{tabular}

${ }^{13} \mathrm{C}$ NMR spectrum was acquired in $\mathrm{CDCl}_{3}$ at $100 \mathrm{MHz}$. Assignments based on HSQC and HMBC experiments.

compound $\mathbf{3}$, the existence of a cross peak between the ${ }^{1} \mathrm{H}$ signal at $\delta_{\mathrm{H}} 6.88$ assigned to $\mathrm{H}-3$ ', and the ${ }^{13} \mathrm{C}$ signal at $\delta_{\mathrm{C}} 123.0$ assigned to $\mathrm{C}-5$, determined the position of the furan ring at C-5 of the indole nucleus. The presence of a carbomethoxy group linked at C-4' was indicated by $\mathrm{HMBC}$ cross peaks between the ${ }^{1} \mathrm{H}$ signals at $\delta_{\mathrm{H}} 8.04$ (H-5', $\delta_{\mathrm{C}} 146.3$ ) and 3.87 (methyl protons) with the ${ }^{13} \mathrm{C}$ signal at $\delta_{\mathrm{C}} 165.0\left(\mathrm{C}-6^{\prime}\right)$. The structure of the new natural product is therefore 5-(4-carbomethoxylfuran-2-yl)- $1 \mathrm{H}$ indole, here named as raputimonoindole B (3). However, compound $\mathbf{3}$ was purified by column chromatography on Sephadex and eluted with $\mathrm{MeOH}-\mathrm{CH}_{2} \mathrm{Cl}_{2}$, hence, 3 could be an artifact.

The ${ }^{1} \mathrm{H}$ NMR resonances for compound 4, when compared to those of $\mathbf{2}$, showed low field shifts for the disubstituted furan ring potons. In compound $\mathbf{4}$, the main difference observed in the ${ }^{1} \mathrm{H}$ NMR, when compared with
3, was the replacement of the resonance for a carbomethoxy group by two ${ }^{1} \mathrm{H}$ singlets at $\delta_{2 \mathrm{H}} 4.11\left(\delta_{\mathrm{C}} 66.0\right)$ and $\delta_{3 \mathrm{H}}$ $3.44\left(\delta_{\mathrm{C}} 57.6\right)$ from a methoxymethylene group. This was supported by the mass spectrum which showed a fragment at $m / z 197\left[\mathrm{C}_{14} \mathrm{H}_{13} \mathrm{NO}_{2}-\mathrm{H}_{2} \mathrm{CO}\right]^{+*}$. These signals together with the mass and ${ }^{13} \mathrm{C}$ NMR spectral data are consistent with 4 being 5-(4-methoxymethylfuran-2yl)- $1 H$-indole, which has previously been isolated from Raputia simulans Kallunki. ${ }^{19}$ However, the isolation of 5-(4-methoxymethylfuran-2-yl)- $1 H$-indole was cited without spectroscopic data in an congress whose abstracts were published in Planta Medica Proceedings. ${ }^{19}$ Thus, its spectroscopic data are cite here for the first time, and it was named raputimonoindole $\mathrm{C}$.

The cinnamic acid (5) derivative showed the spectral characteristic of a trans $\alpha, \beta$-unsaturated carboxyl functional group $\left(\delta_{\mathrm{H} \beta} 7.61, \mathrm{~d}, J 15.9, \delta_{\mathrm{C} \beta} 144.5 ; \delta_{\mathrm{H \alpha}} 6.29\right.$, d, $J$ 15.9, $\delta_{\mathrm{C} \alpha} 115.7$; COOR 167.3). In addition, the ${ }^{1} \mathrm{H}$ NMR showed signals for one methoxyl group at $\delta_{\mathrm{H}} 3.92\left(\mathrm{~s}, 3 \mathrm{H} ; \delta_{\mathrm{C}}\right.$ $55.9)$, three aromatic hydrogens at $\delta_{\mathrm{H}} 7.07(\mathrm{dd}, 8.1,1.7 \mathrm{~Hz})$, $7.03(\mathrm{~d}, 1.7 \mathrm{~Hz})$ and $6.91(\mathrm{~d}, 8.1 \mathrm{~Hz})$, clearly indicating the aromatic ring to be 1,2,4-trisubstituted. From the HMBC experiments, the cross peaks observed between the signal of methoxyl group at $\delta_{3 \mathrm{H}} 3.92$ with $\delta_{\mathrm{C}} 146.7$, and the ${ }^{1} \mathrm{H}$ signal at $\delta_{\mathrm{H}} 7.61\left(\mathrm{H}-3^{\prime}\right)$ with $\delta_{\mathrm{C}} 147.9$ but not with $\delta_{\mathrm{C}} 146.7$, indicated the presence of a 2-hydroxy-4-methoxy-cinnamic acid derivative. The ${ }^{13} \mathrm{C}$ NMR spectrum revealed resonances for an aliphatic chain of sixteen carbons, one being attached to carboxylate as indicated by the HMBC cross peak between the ${ }^{1} \mathrm{H}$ signal at $\delta_{\mathrm{H}} 4.18$ and the ${ }^{13} \mathrm{C}$ signal at $\delta 167.3$ (C-1'). The presence of a hexadecanyl chain was corroborated by the MS spectrum, which showed an ion at $\mathrm{m} / \mathrm{z}, 279\left[\mathrm{HC} \equiv \mathrm{C}-\mathrm{COO}-\left(\mathrm{CH}_{2}\right)_{14}-\mathrm{CH}_{2}\right]^{+}$. The new compound was therefore identified as hexadecanyl 2-hydroxy-4methoxy-cinnamate (5). The structural assignment was also supported by comparison of its ${ }^{13} \mathrm{C}$ NMR spectrum with that of 4-hydroxy-2- methoxy-cinnamic acid. ${ }^{20}$

A number of 3,5- and 3,6-diprenylated indoles have been reported for the Annonaceae genera Isolona, ${ }^{21-23}$ Uvaria, ${ }^{22}$ Annonidium, ${ }^{24}$ Monodora, ${ }^{25}$ Hexalobus, ${ }^{26}$ Asteranthe, ${ }^{27}$ Greenwayodendron, ${ }^{28}$ and Polyalthia. ${ }^{29}$ However, there are only a few examples of 3-, 5-, 6- and 7- and 3,7-prenylated indoles reported in the Rutaceae genera Raputia, ${ }^{14}$ Esenbeckia, ${ }^{30,31}$ Murraya, ${ }^{32-34}$ Merrillia $^{35}$ and Glycosmis. ${ }^{36,37}$ Four bisindoles (6-9; Figure 3) similar to compound $\mathbf{1}$ have been isolated from Raputia simulans. ${ }^{14}$ One bisindole, yuehchukene, which may be regarded as the product of Diels-Alder-type condensation of two 3-isopentenylindoles, occurs in Murraya species. ${ }^{32}$ While several bisindoles derived from 2-prenyltryptamine have been isolated from Flindersia species (Rutaceae), ${ }^{38}$ 
pyrano[3,2-b]indole skeleton (koniamborine), a novel type of alkaloid was isolated from Boronella koniambiensis (Rutaceae). ${ }^{39}$

The anthranilate alkaloid content found in $R$. praetermissa indicates that the genus is strongly related to those included in Cusparieae tribe. As mentioned in the introduction, the polimethoxylated flavonoids form an extremely good marker for the Neoraputia. Their use in this context shows that $R$. praetermissa differs substantially from Neoraputia species, and reinforce its inclusion in Raputia genus. Furthermore, the prenylindole alkaloids have been reported only from Esenbeckia and Raputia in Cusparieae, thus suggesting an affinity of this tribe with subfamily Aurantioideae, where similar prenylindoles occur in Murraya, ${ }^{33-35}$ Merrillia $^{36}$ and Glycosmis. ${ }^{37,38}$ It is noteworthy that Neoraputia shares with Murraya and Citrus a propensity for producing polymethoxylated flavonoids, $, 12,40,41$ showing also chemical affinity with Aurantioideae.

\section{Experimental}

\section{General experimental procedures}

Optical rotations were measured by using a Perkin Elmer 241 spectropolarimeter; NMR: Bruker DRX 400, with TMS as internal standard; high resolution EIMS: Fisons VG Autospec; GC-MS: low resolution on a HP-2576 instrument; IR: Bomen-FT/IR; UV: Hewlett Packard/8452A; Elemental analyses: on a EA 1108, CHNS-O (Fisons).

\section{Plant material}

Raputia praetermissa was collected in the Forest Reserve Adolpho Ducke, Amazonas, Brazil, and identified by J. R. Pirani (Department of Botany, University of São Paulo). A voucher specimen (189865) is deposited in the Herbarium of the Instituto Nacional de Pesquisa da Amazônia (INPA), Manaus, AM (Brazil).

\section{Extraction and isolation}

Ground stems $(4.4 \mathrm{~kg})$ were extracted 3 times at room temperature using hexane, followed by $\mathrm{CH}_{2} \mathrm{Cl}_{2}$ and $\mathrm{MeOH}$. The concentrated hexane extract (13.3 g) was subjected to silica gel (230-400 mesh) column chromatography with successive elution with hexane, $\mathrm{CH}_{2} \mathrm{Cl}_{2}, \mathrm{EtOAc}$ and $\mathrm{MeOH}$, yielding 6 fractions. Fraction 2 was flash rechromatographed twice on silica gel with successive elution with hexane, $\mathrm{CH}_{2} \mathrm{Cl}_{2}$, EtOAc and $\mathrm{MeOH}$, and then by preparative TLC (silica gel; hexane-acetone 9:1), yielding cycloartenone $(10 \mathrm{mg})$. Fraction 3 was flash rechromatographed twice as above, and then by gel permeation column chromatography (Sephadex LH 20, $\mathrm{CH}_{2} \mathrm{Cl}_{2}-\mathrm{MeOH} 2: 8$ ) affording $\mathrm{N}$-methyl-4-methoxyquinolin-2(1H)-one $(30 \mathrm{mg})$. Fraction 4 was chromatographed on silica gel and Florisil (1:1) with hexane-EtOAc-MeOH gradient elution to give two fractions (A and B). Fraction A was subjected to column chromatography over silica gel and eluted with hexane-acetone gradient, yielding a mixture of sitosterol and stigmasterol. Fraction B was purified by preparative TLC (silica gel; hexane-acetone 9:1), yielding sitostenone $(60 \mathrm{mg})$. Fraction 5 was chromatographed on silica gel and Florisil (1:1) with hexane-EtOAc-MeOH gradient elution to give skimmianine $(50 \mathrm{mg}$ ).

The concentrated dichloromethane extract $(30.0 \mathrm{~g})$ was subjected to column chromatography over silica gel (70-230 mesh) under vacuum. Elution with hexane, $\mathrm{CH}_{2} \mathrm{Cl}_{2}$, EtOAc and $\mathrm{MeOH}$ yielded 4 fractions. Fraction 1 was flash rechromatographed on silica gel with hexane-EtOAc-MeOH gradient, yielding compound $\mathbf{1}(700 \mathrm{mg})$ and a new fraction C. Fraction $\mathrm{C}$ was flash rechromatographed twice as above, and then by preparative TLC (silica gel; hexane-acetone $6: 1$ ), yielding compound 5 . Fraction 2 was chromatographed on silica gel and Florisil (1:1) with hexane-acetone-MeOH gradient elution to give new fractions D, E and F. Fractions $\mathrm{D}$ and $\mathrm{E}$ were rechromatographed over Sephadex LH $20(\mathrm{MeOH})$ to give compounds $\mathbf{2}$ and $\mathbf{4}$, respectively. Fraction $\mathrm{F}$ was flash rechromatographed on silica gel with hexane-acetone- $\mathrm{MeOH}$ gradient elution, yielding robustine $(50 \mathrm{mg})$. Fraction 3 was rechromatographed as above using hexane- $\mathrm{CH}_{2} \mathrm{Cl}_{2}-\mathrm{MeOH}$ gradient to yield two fractions. Both fractions were rechromatographed over Sephadex LH 20 ( $\mathrm{MeOH}-\mathrm{CH}_{2} \mathrm{Cl}_{2} 2: 8$ ) affording maculosidine $(80 \mathrm{mg}$ ), and a new fraction containing compound $\mathbf{3}$ which was purified by preparative TLC (silica gel; hexane-acetone 5:1). Fraction 4 was rechromatographed on silica gel and Florisil (1:1) with hexane-acetone-MeOH gradient elution to give evolitrine $(50 \mathrm{mg}$ ) and dictamnine $120 \mathrm{mg}$ ).

\section{4-Deoxyraputindole $C(\mathbf{1})$}

Brown solid; $[\alpha]_{\mathrm{D}}{ }^{25}+94\left(\mathrm{CHCl}_{3} ; c 0.0012\right) ; \mathrm{UV}$ (acetone) $\lambda_{\max } / \mathrm{nm}: 230 ; \mathrm{IR}(\mathrm{KBr}) v_{\max } / \mathrm{cm}^{-1}: 3425.7 ;{ }^{1} \mathrm{HNMR}$ (400 MHz, $\mathrm{CDCl}_{3}$ ), see Table $1 ;{ }^{13} \mathrm{C}$ NMR $(100 \mathrm{MHz}$, $\mathrm{CDCl}_{3}$ ), see Table 2; HREI-MS, 366.20560 (37.5; calc. for $\mathrm{C}_{26} \mathrm{H}_{26} \mathrm{~N}_{2}$ ), 294.11201(10.0), 223.13387 (100), 167.07123 (20), 130.06388 (30).

\section{Raputimonoindole A (2)}

Yellow solid; $[\alpha]_{\mathrm{D}}{ }^{25}-41\left(\mathrm{CHCl}_{3} ; c 0.003\right)$; UV (acetone)

$\lambda_{\max } / \mathrm{nm}: 228$; IR (KBr) $v_{\max } / \mathrm{cm}^{-1}: 3411.5 ;{ }^{1} \mathrm{H}$ NMR 
(400 MHz, $\mathrm{CDCl}_{3}$ ), see Table $1 ;{ }^{13} \mathrm{CNMR} / \mathrm{DEPT}(100 \mathrm{MHz}$, $\mathrm{CDCl}_{3}$ ), see Table 2. Anal. found C $80.28 \%, \mathrm{H} 7.80 \%, \mathrm{~N}$ 5.20\%; calc. for $\mathrm{C}_{18} \mathrm{H}_{21} \mathrm{NO}, \mathrm{C} 80.86 \%, \mathrm{H} 7.92 \%$, N 5.24\%, O $5.98 \%$; MS m/z $267[\mathrm{M}]^{+\bullet}(10), 252$ (5), 211 (50), 144 (100), 107 (80), 79 (70).

\section{Raputimonoindole B (3)}

Yellow solid; UV (acetone) $\lambda_{\max } / \mathrm{nm}$ : $230 ; \mathrm{IR}(\mathrm{KBr})$ $v_{\max } / \mathrm{cm}^{-1}: 3310.2,1770.1 ;{ }^{1} \mathrm{H}$ NMR $\left(400 \mathrm{MHz}, \mathrm{CDCl}_{3}\right)$, see Table $1 ;{ }^{13} \mathrm{C}$ NMR/DEPT (100 MHz, $\mathrm{CDCl}_{3}$ ), see Table 2. Anal. found C 69.76\%, H 4.58\%, N 5.80\%; calc. for $\mathrm{C}_{14} \mathrm{H}_{11} \mathrm{NO}_{3}, \mathrm{C} 69.70 \%, \mathrm{H} 4.60 \%$, N 5.81\%, O $19.90 \%$; MS $m / z 241[\mathrm{M}]^{+*}(100), 226\left[\mathrm{C}_{14} \mathrm{H}_{11} \mathrm{NO}_{3}-\mathrm{Me}\right]^{+}(15), 210$ $\left[\mathrm{C}_{14} \mathrm{H}_{11} \mathrm{NO}_{3}-\mathrm{OMe}\right]^{+}(10), 198(10), 154(30), 105$ (40), 77 (50).

\section{Raputimonoindole C (4)}

Yellow solid; UV (acetone) $\lambda_{\max } / \mathrm{nm}$ : 232 ; IR (KBr) $v_{\max } / \mathrm{cm}^{-1}: 3315.4 ;{ }^{1} \mathrm{H}$ NMR (400 MHz, $\mathrm{CDCl}_{3}$ ), see Table 1; ${ }^{13} \mathrm{C}$ NMR/DEPT (100 MHz, $\mathrm{CDCl}_{3}$ ), see Table 2. Anal. found C 73.90\%, $\mathrm{H} 5.80 \%$, N 6.15\%; calc. for $\mathrm{C}_{14} \mathrm{H}_{13} \mathrm{NO}_{2}$, C 73.99\%, H 5.77\%, N 6.16\%, O 14.08\%; MS m/z 227 [M] $]^{+}$ (100), 197 (80), 168 (70), 98 (30).

\section{Hexadecanyl 2-hydroxy-4-methoxy-cinnamate (5)}

Amorphous white solid; ${ }^{1} \mathrm{H}$ NMR $\left(400 \mathrm{MHz}, \mathrm{CDCl}_{3}\right)$ : $\delta 7.61(\mathrm{~d}, J 15.9 \mathrm{~Hz}, \mathrm{H}-3$ ') 7.07 (dd, $J 8.1,1.7 \mathrm{~Hz}, \mathrm{H}-5), 7.03$ (d, $J 1.7 \mathrm{~Hz}, \mathrm{H}-3), 6.91$ (d, $J 8.1 \mathrm{~Hz}, \mathrm{H}-6), 6.29$ (d, $J$ 15.9, H-2'), 3.92 (s, OMe), 4.18 (t, J 6.8 Hz, H-1"), 1.69 (quint, $J 6.8 \mathrm{~Hz}, \mathrm{H}-2$ "), 1.25 (br s, 3"-15") and 0.88 (t, $J 6.6 \mathrm{~Hz}$, $\mathrm{H}-16) ;{ }^{13} \mathrm{C}$ NMR (100 MHz, $\left.\mathrm{CDCl}_{3}\right): \delta 167.3$ (C-1'), 147.9 (C-2), 146.7 (C-4), 144.5 (C-3'), 127.0 (C-1), 123.0 (C-5), 115.7 (C-2'), 114.6 (C-6), 109.3 (C-3), 64.5 (C-1”), 55.9 (OMe), 29.6-28.7 (C-3"-C-15"), 14.0 (C-16"); MS m/z 418 $[\mathrm{M}]^{+\bullet}(5), 279(10), 207\left[279-\mathrm{C}_{5} \mathrm{H}_{12}\right]^{+}(10), 167(50), 149$ (100), 71 (40), 57 (45).

\section{Note from the Editor}

During the edition of the present paper, the spectroscopic data of compound $\mathbf{4}$ have been published online on March 7, 2011 by Planta Medica, in the entitled Letter "Simple Indole Alkaloids from the Neotropical Rutaceous Tree Raputia simulans" by K. Vougogiannopoulou, N. Fokialakis, N. Aligiannis, C. Cantrel, A-L Skaltsounis.

\section{Supplementary Information}

${ }^{1} \mathrm{H}$ and ${ }^{13} \mathrm{C}$ NMR spectra of compounds 1-5 are available free of charge at http://jbcs.sbq.org.br as PDF file.

\section{Acknowledgments}

The authors thank the Brazilian agencies, Institutos Nacionais de Ciência e Tecnologia - Conselho Nacional de Desenvolvimento Cientifico e Tecnológico (CNPq/MCT), Fundação de Amparo a Pesquisa do Estado de São Paulo (FAPESP), Coordenação de Aperfeiçoamento de Pessoal de Ensino Superior (CAPES) and Financiadora de Estudos e Projetos (FINEP) for their financial support.

\section{References}

1. Aublet, J. B. C. F.; Histoire des Plantes de la Guiane Françoise, Vol. 2; P. E. Didot: London and Paris, 1775; Emmerich, M.; Rodriguesia 1978, 30, 223.

2. Kallunki, J. A.; Brittonia 1990, 42, 175.

3. Kallunki, J. A.; Brittonia 1994, 46, 279.

4. Kallunki, J. A.; Brittonia 2009, 61, 28.

5. Pirani, J. R.; Rodriguesia 2005, 56, 189.

6. Arruda, A. C.; Vieira, P. C.; Fernandes, J. B.; da Silva, M. F. G. F.; Francisco, R. H. P.; Rodrigues, A. M. G. D.; Lechat, J. R.; Phytochemistry 1991, 30, 3157.

7. Arruda, A. C.; Vieira, P. C.; Fernandes, J. B.; da Silva, M. F. G. F.; J. Braz. Chem. Soc. 1993, 4, 80.

8. Passador, E. A. P.; da Silva, M. F. G. F.; Rodrigues-Fo, E.; Fernandes, J. B.; Vieira, P. C.; Pirani, J. R.; Phytochemistry 1997, 45, 1533.

9. Tomazela, D. M.; Pupo, M. T.; Passador, E. A. P.; da Silva, M. F. G. F.; Vieira, P. C.; Fernandes, J. B.; Rodrigues-Fo, E.; Oliva, G.; Pirani, J. R.; Phytochemistry 2000, 55, 643.

10. Souza, J. P. I.; Arruda, A. C.; Arruda, M. S. P.; Fitoterapia 1995, $66,465$.

11. Souza, J. P. I.; Arruda, A. C.; Muñoz, G. D.; Arruda, M. S. P.; Müller, A. H.; Phytochemistry 1999, 52, 1705.

12. Moraes, V. R. S; Tomazela, D. M.; Ferracin, R. J.; Garcia, C. F.; Sannomiya, M.; Soriano, M. P. C.; da Silva, M. F. G. F.; Vieira, P. C.; Fernandes, J. B.; Rodrigues-Fo, E.; Magalhães, E. G.; Magalhães, A. F.; Pimenta, E. F.; de Souza, D. H. F.; Oliva, G.; J. Braz. Chem. Soc. 2003, 14, 380.

13. Bakhtiar, A.; Gleye, J.; Moulis, C.; Fouraste, I.; Phytochemistry 1991, 30, 3840.

14. Vougogiannopoulou, K.; Fokialakis, N.; Aligiannis, N.; Cantrell, C.; Skaltsounis, A.-L.; Org. Lett. 2010, 12, 1908.

15. Robertson, A. V.; Aust. J. Chem. 1963, 16, 451.

16. Cortez, L. E. R.; Cortez, D. A. G.; Ferreira, A. G.; Vieira, P. C.; da Silva, M. F. G. F.; Fernandes, J. B.; Braz. J. Pharmacogn. 2006, 16, 164.

17. Nayar, M. N. S.; Sutar, C. V.; Bhan, M. K.; Phytochemistry 1971, 10, 2843.

18. Khuong-Huu, F.; Sangare, M.; Chari, V. M.; Bekaert, A.; Devys, M.; Barbier, M.; Lukacs, G.; Tetrahedron Lett. 1975, 1787. 
19. Vougogiannopoulou, K.; Fokialakis, N.; Aligiannis, N.; Cantrell, C.; Skaltsounis, A.-L.; Planta Med. 2008, 74, 189.

20. Chen, H.; Jiang, H.; Morgan, J. A.; Phytochemistry 2007, 68, 306.

21. Makangara, J. J.; Henry, L.; Jonker, S. A.; Nkunya, M. H. H.; Phytochemistry 2004, 65, 227.

22. Achenbach, H.; Raffelsberger, B.; Tetrahedron Lett. 1979, 28 , 2571.

23. Achenbach, H.; Löwel, M.; Phytochemistry 1995, 40, 967.

24. Achenbach, H.; Renner, C.; Heterocycles 1985, 23, 2075.

25. Adeoye, A. O.; Oguntimein, B. O.; Clark, A. M.; Hufford, C. D.; J. Nat. Prod. 1986, 49, 534.

26. Achenbach, H.; Renner, C.; Addae-Mensah, I.; Heterocycles 1984, 22, 2501.

27. Nkunya, M. H. H.; Jonker, S. A.; Mdee, L. K.; Waibel, R.; Achenbach, H.; Nat. Prod. Lett. 1996, 9, 71.

28. Yoo, H-D.; Cremin, P. A.; Zeng, L.; Garo, E.; Williams, C. T.; Lee, C. M.; Goering, M. G.; O’Neil-Johnson, M.; Eldridge, G. R.; Hu, J-F.; J. Nat. Prod. 2005, 68, 122.

29. Kunesch, N.; Cave, A.; Leboeuf, M.; Hocquemiller, R.; Dubois, G.; Guittet, E.; Lallemand, J. Y.; Tetrahedron Lett. 1985, 26, 4937.

30. Monache, F. D.; Monache, G. D.; Souza, M. A. M.; Cavalcanti, M. S.; Chiappeta, A.; Gazz. Chim. Ital. 1989, 119, 435.

31. Monache, F. D.; Benedito R. D.; Gazz. Chim. Ital. 1990, 120, 387.

32. Kinoshita, T.; Tatara, S.; Ho, F-G.; Sankawa, U.; Phytochemistry 1989, 28, 147.
33. Wu, T-S.; Liou, M-J.; Jong, T-T.; Chen, Y-J.; Lai, J-S.; Phytochemistry 1989, 28, 2873.

34. Wu, T-S.; Liou, M-J.; Lee, C-J.; Jong, T-T.; McPhail, A. T.; McPhail, D. R.; Lee, K-H.; Tetrahedron Lett. 1989, 30, 6649.

35. Kong, Y-C.; But, P. P-H; NG, K-H.; Cheng, K-F; Chang, K-L.; Wong, K. M.; Gray, A. I.; Waterman, P. G.; Biochem. Syst. Ecol. 1988, $16,47$.

36. Vajrodaya, S.; Bacher, M.; Greger, H.; Hofer, O.; Phytochemistry 1998, 48, 897.

37. Wang, J.; Zheng, Y.; Efferth, T.; Wang, R.; Shen, Y.; Hao, X.; Phytochemistry 2005, 66, 697.

38. Fernandez, L. S.; Buchanan, M. S.; Carroll, A. R.; Feng, Y. J.; Quinn, R. J.; Avery, V. M.; Org. Lett. 2009, 11, 329.

39. Grougnet, R.; Magiatis, P.; Fokialakis, N.; Mitaku, S.; Skaltsounis, A-L.; Tillequin F.; Sevenet, T.; Litaudon, M.; J. Nat. Prod. 2005, 68, 1083.

40. Ferracin, R. J.; da Silva, M. F. G. F.; Fernandes, J. B; Vieira, P. C.; Phytochemistry 1998, 47, 393.

41. Ribeiro, A. B.; Abdelnur, P. V.; Garcia, C. F.; Belini, A.; Severino, V. G. P.; da Silva, M. F. G. F.; Fernandes, J. B.; Vieira, P. C.; de Carvalho, S. A.; de Souza, A. A.; Machado, M. A.; J. Agric. Food Chem. 2008, 56, 7815.

Submitted: October 4, 2010

Published online: March 24, 2011

FAPESP has sponsored the publication of this article. 


\section{Prenylindole Alkaloids from Raputia praetermissa (Rutaceae) and their}

Chemosystematic Significance

Lisandra V. Rosas, Thiago André M. Veiga, João B. Fernandes, Paulo C. Vieira and M. Fátima das G. F. da Silva*

Departamento de Química, Universidade Federal de São Carlos,

CP 676, 13565-905 São Carlos-SP, Brazil
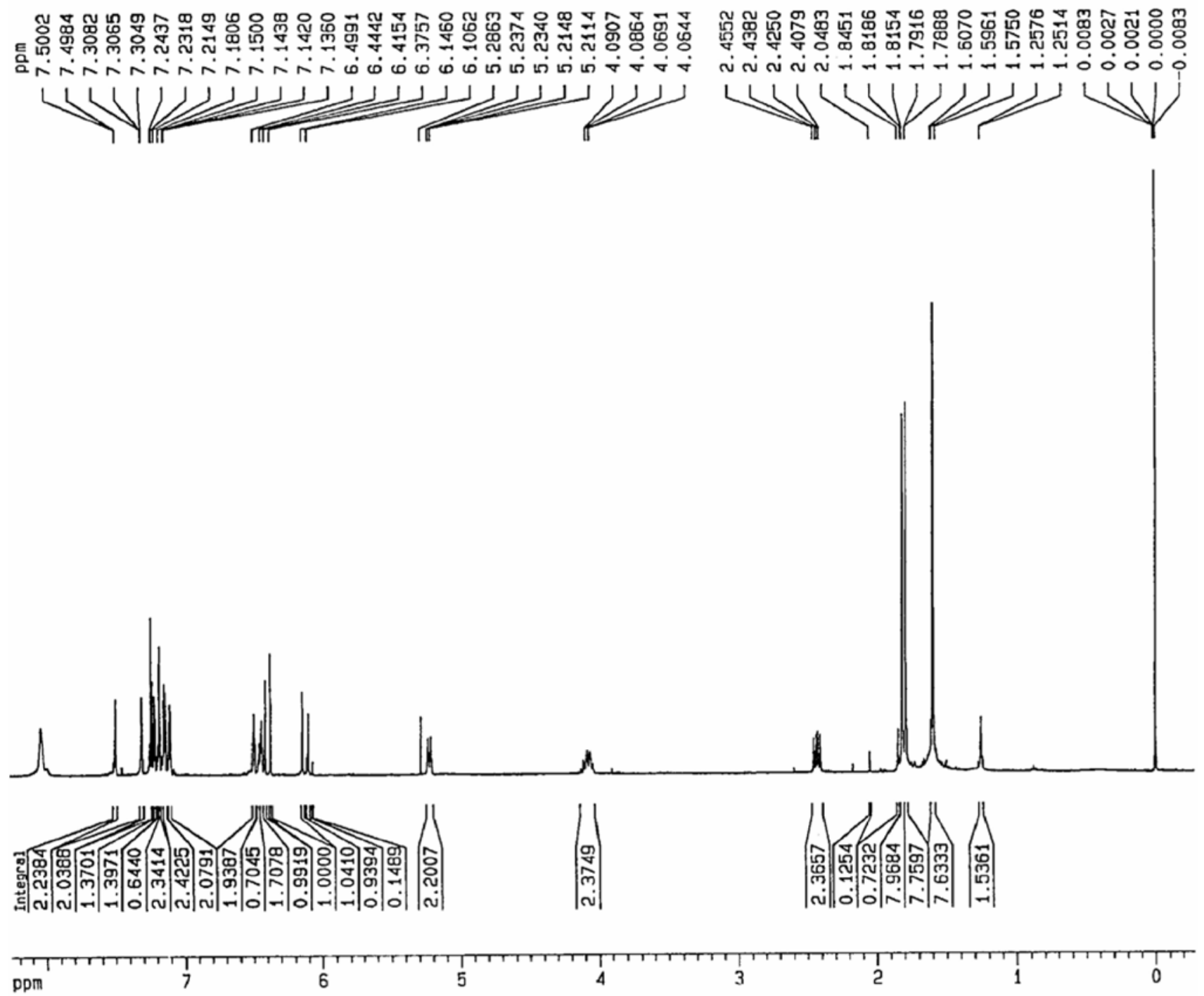

Figure S1. ${ }^{1} \mathrm{H}$ NMR spectrum of $\mathbf{1}$. 

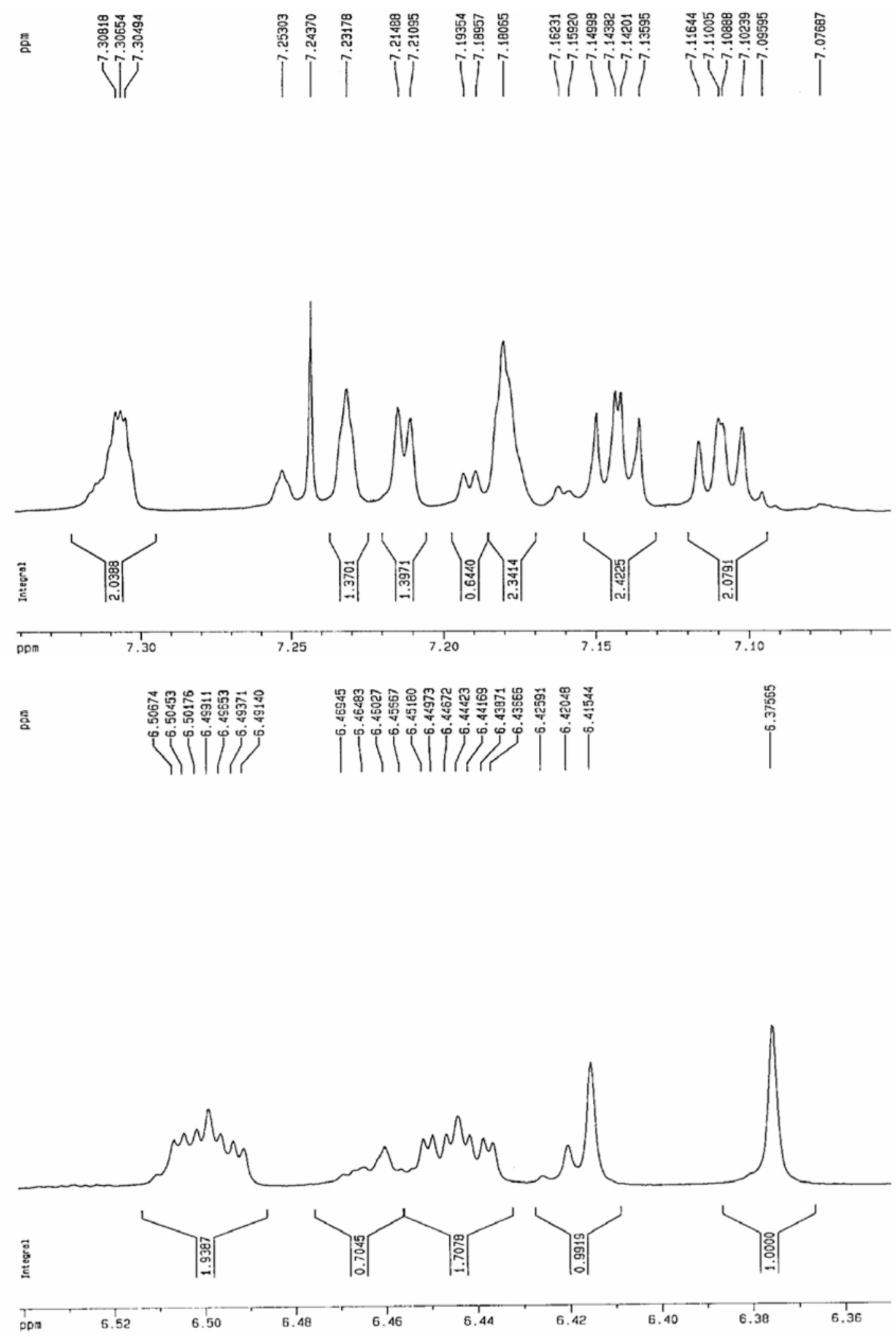

Figure S2. Expanded ${ }^{1} \mathrm{H}$ NMR spectrum of $\mathbf{1}$. 

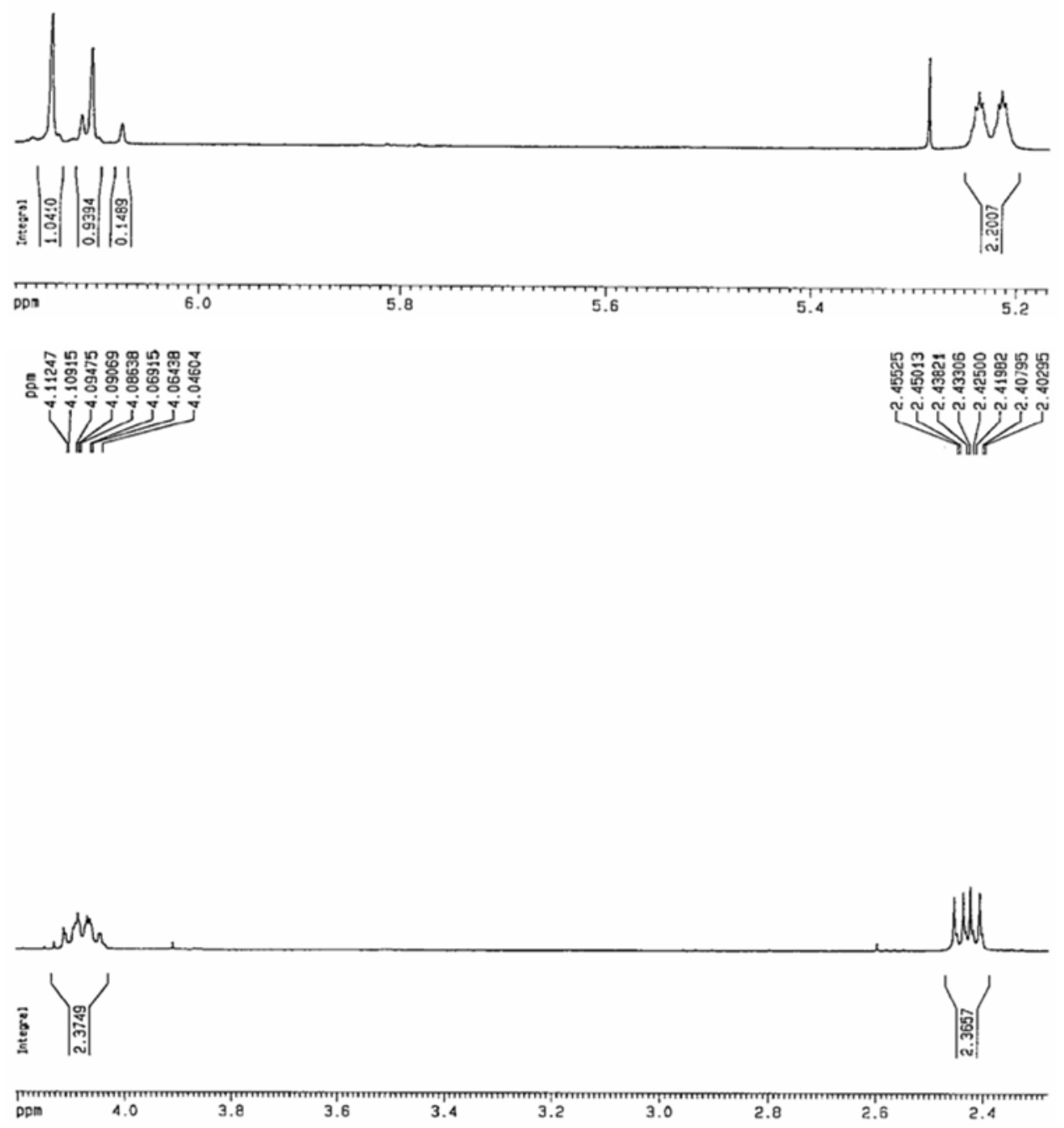

Figure S3. Expanded ${ }^{1} \mathrm{H}$ NMR spectrum of $\mathbf{1}$. 


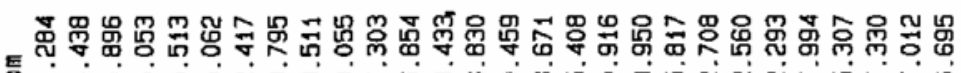

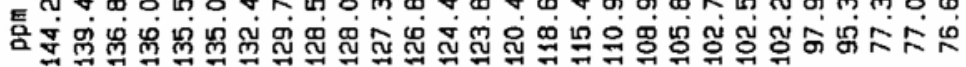

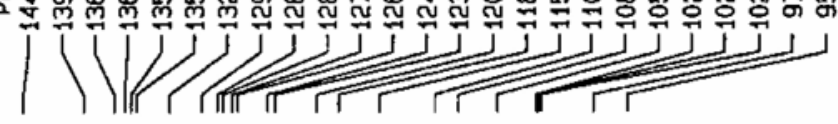

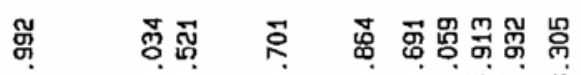

i.

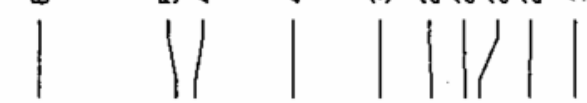

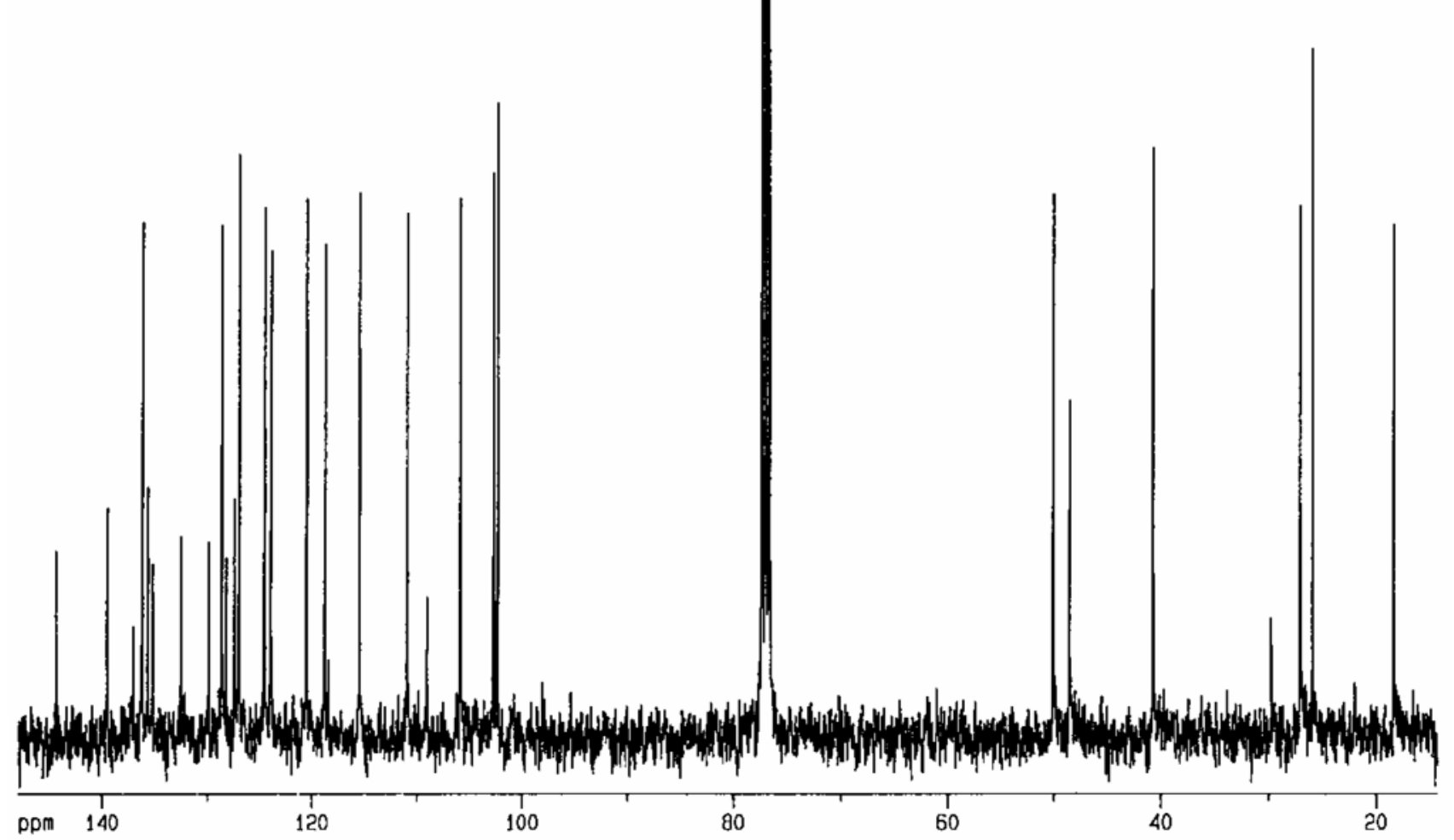

Figure S4. ${ }^{13} \mathrm{C}$ NMR spectrum of $\mathbf{1}$. 


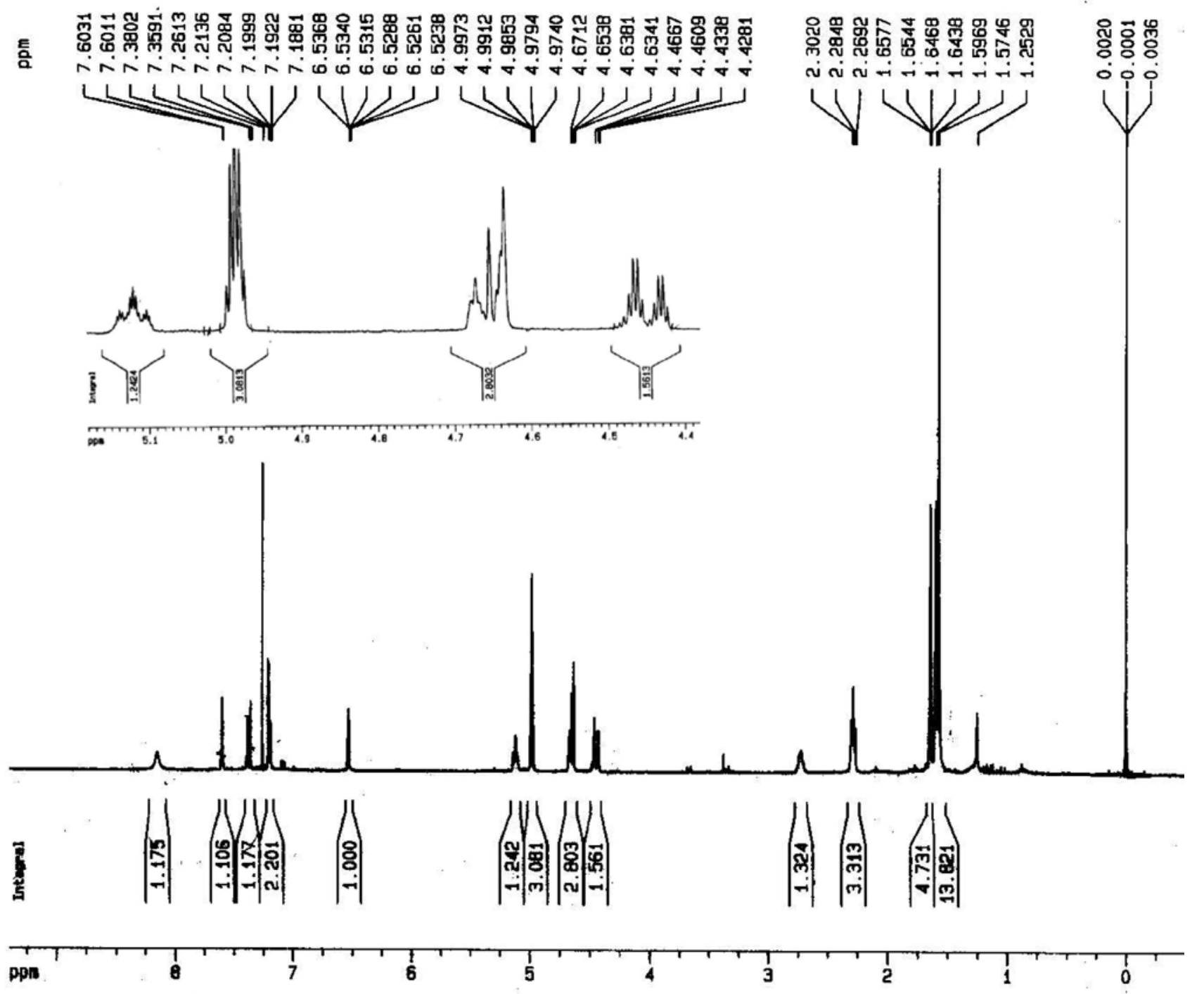

Figure S5. ${ }^{1} \mathrm{H}$ NMR spectrum of 2. 


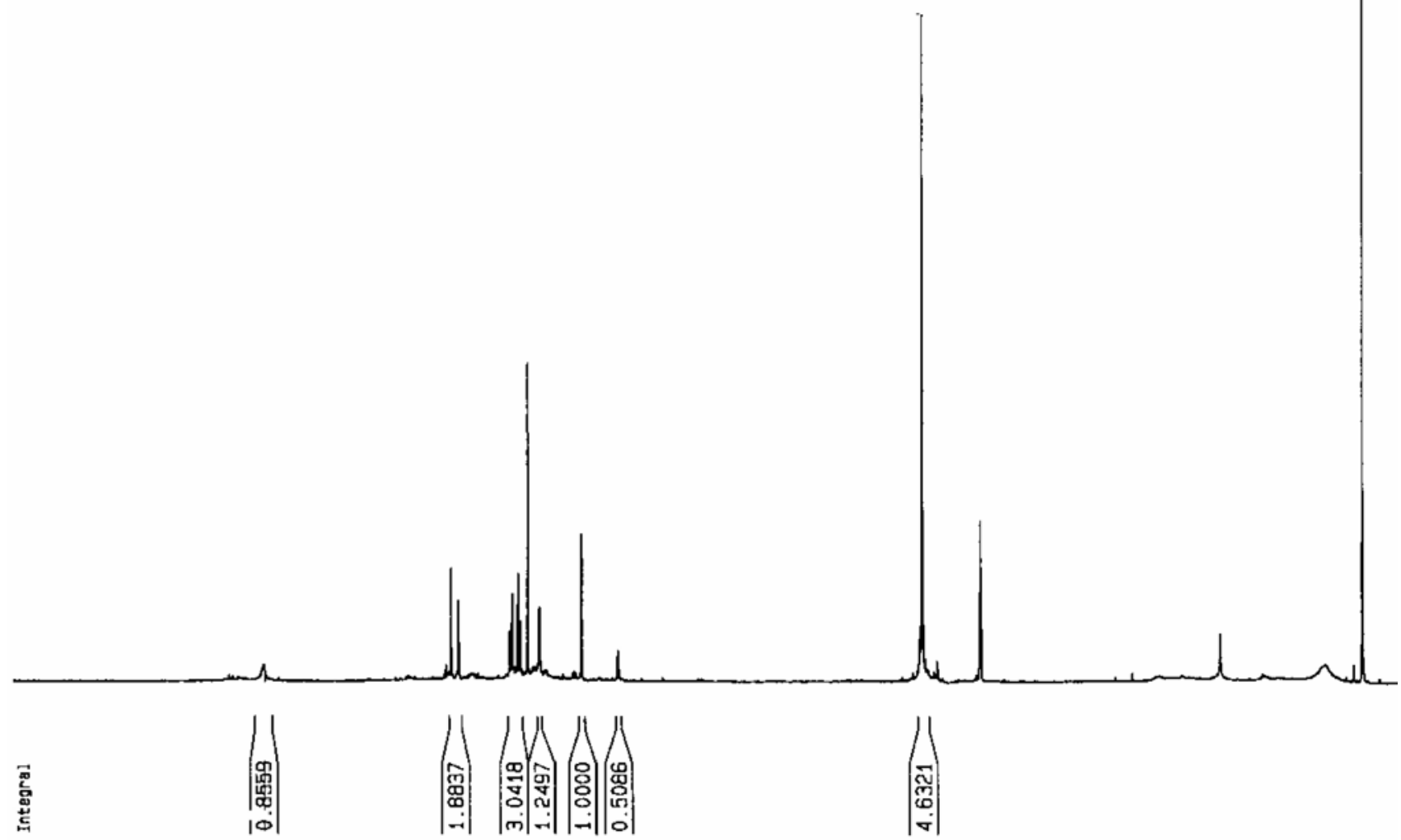

ppm 10

Figure S7. ${ }^{1} \mathrm{H}$ NMR spectrum of 3 . 


\section{|}
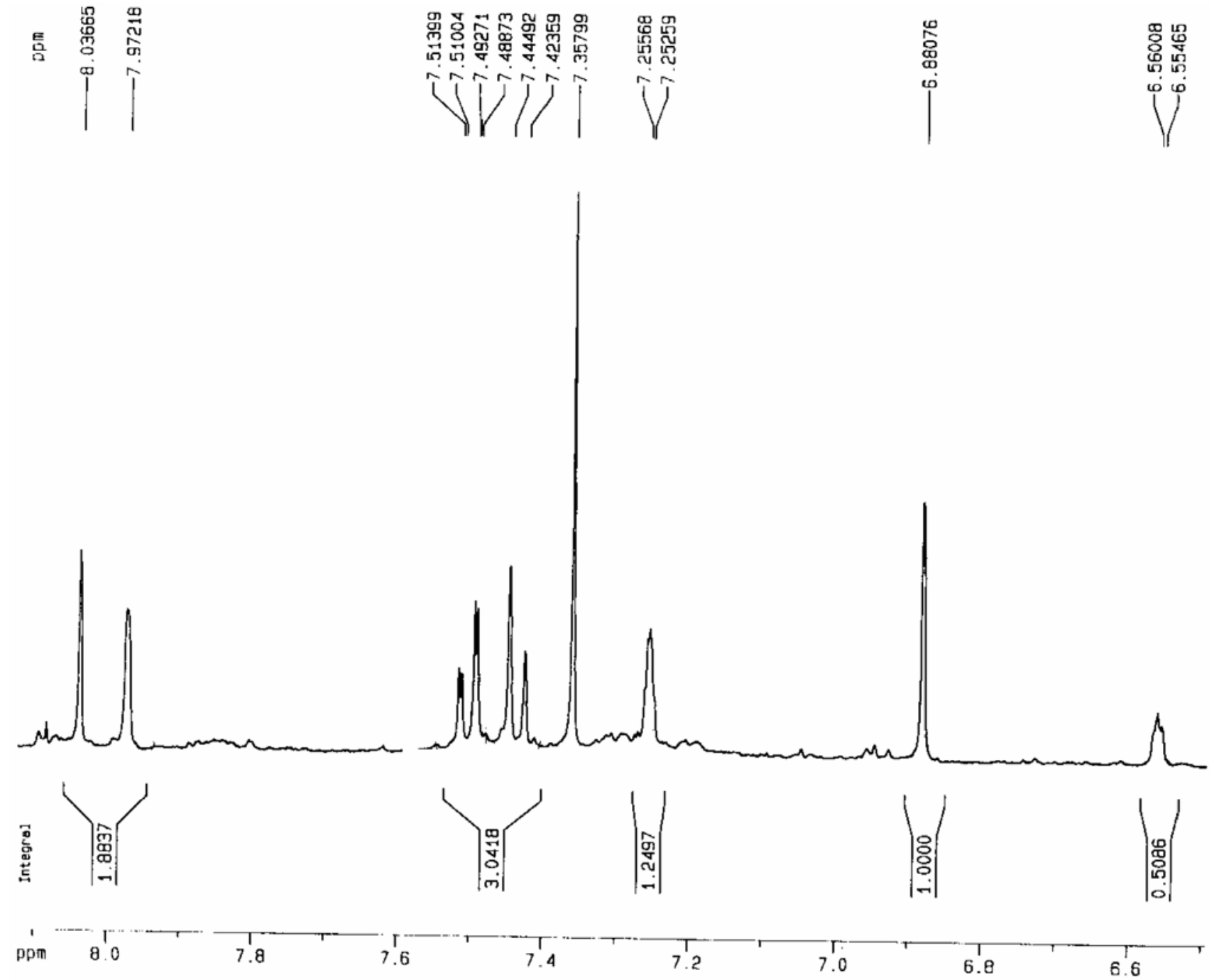

Figure S8. Expanded ${ }^{1} \mathrm{H}$ NMR spectrum of 3 . 


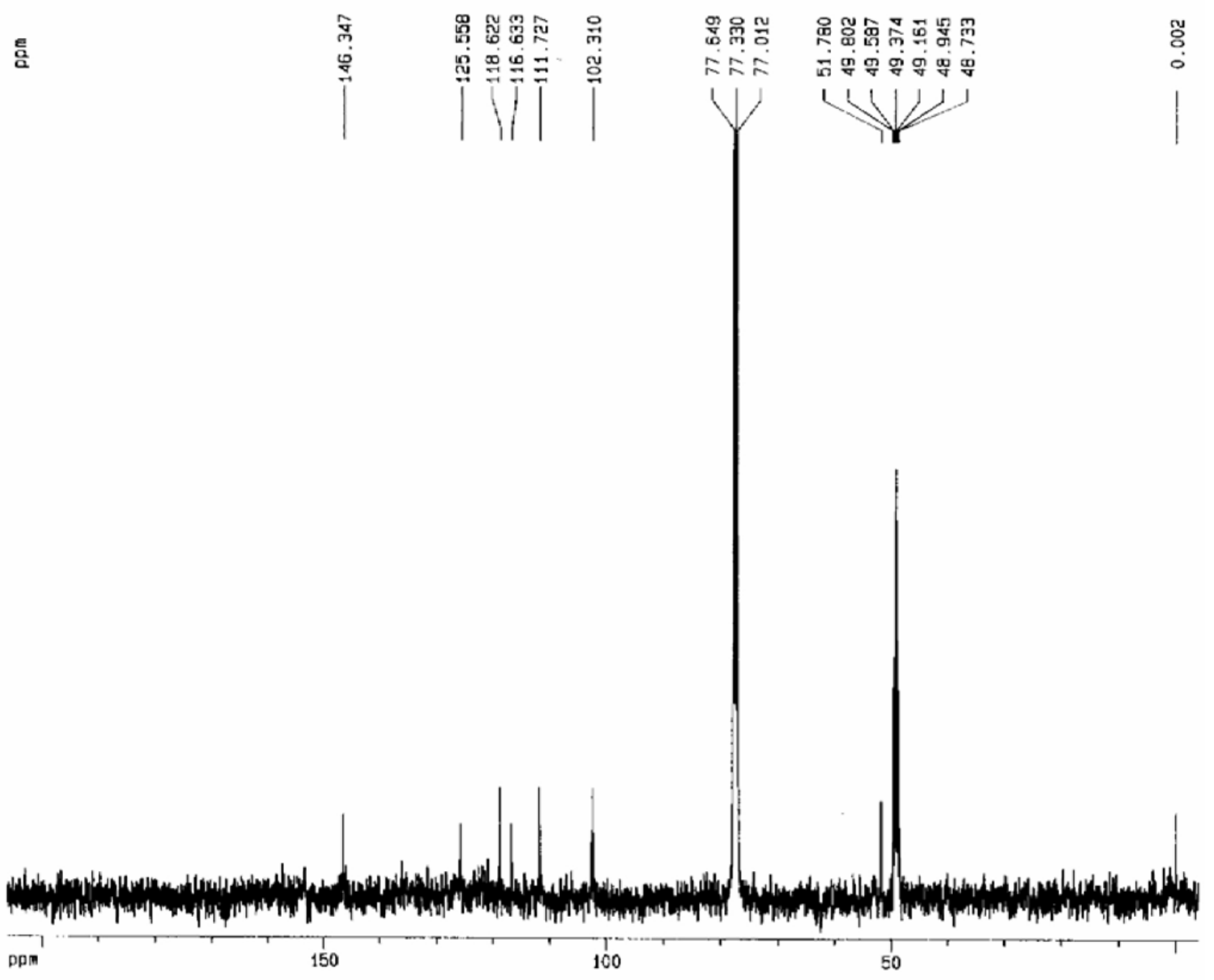

Figure S9. ${ }^{13} \mathrm{C}$ NMR spectrum of $\mathbf{3}$. 

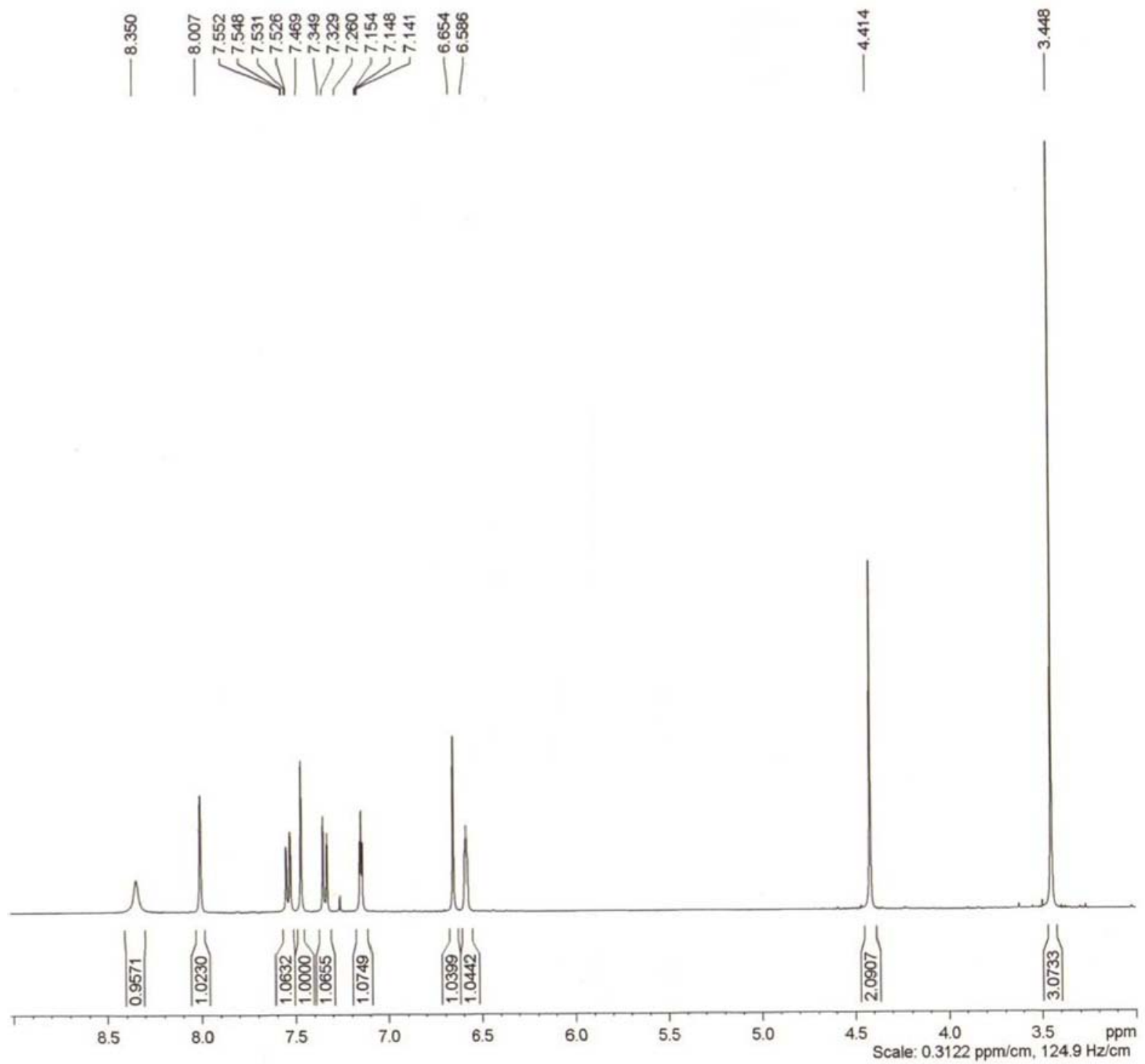

Figure S10. ${ }^{1} \mathrm{H}$ NMR spectrum of 4. 

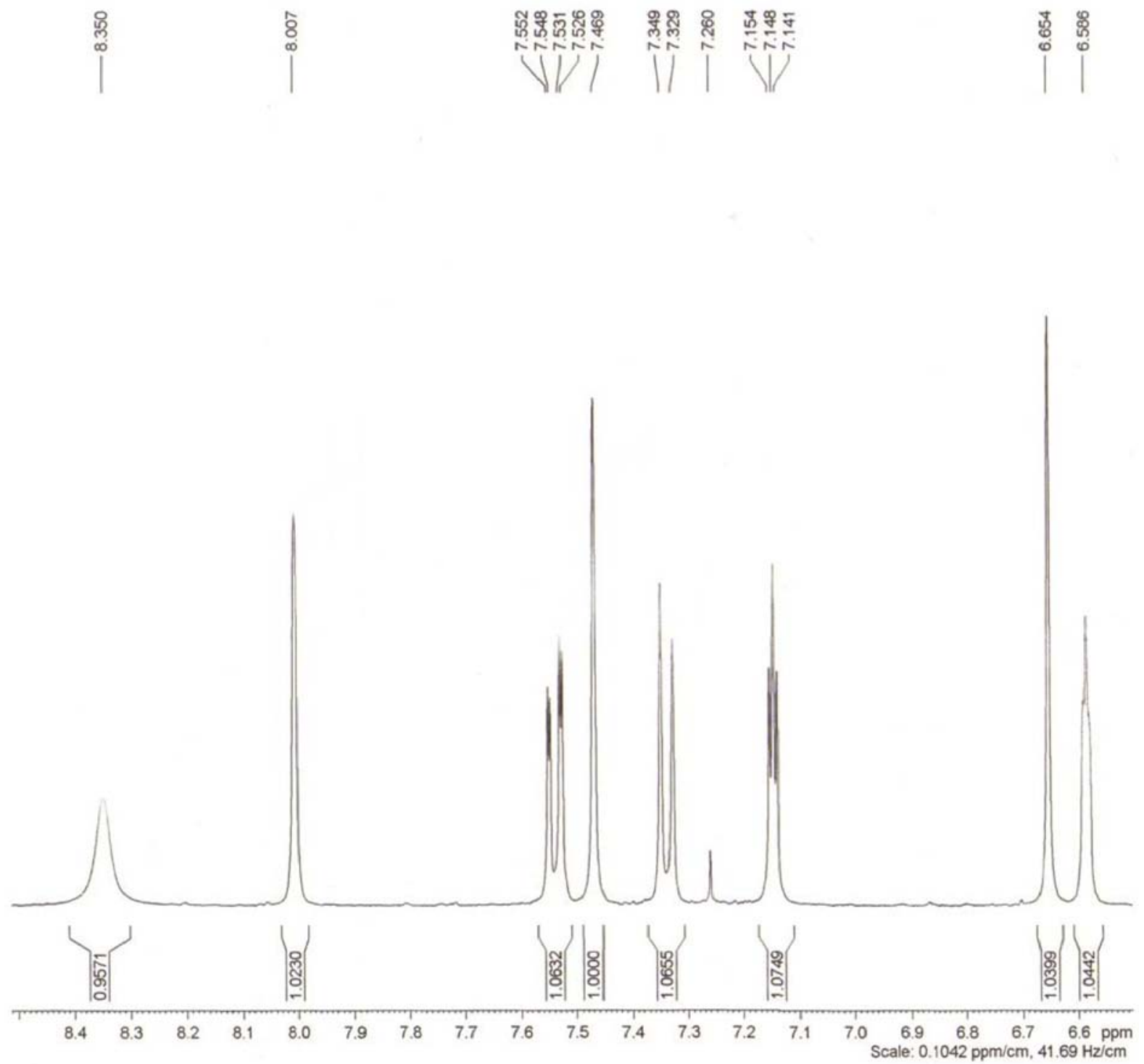

Figure S11. Expanded ${ }^{1} \mathrm{H}$ NMR spectrum of 4. 


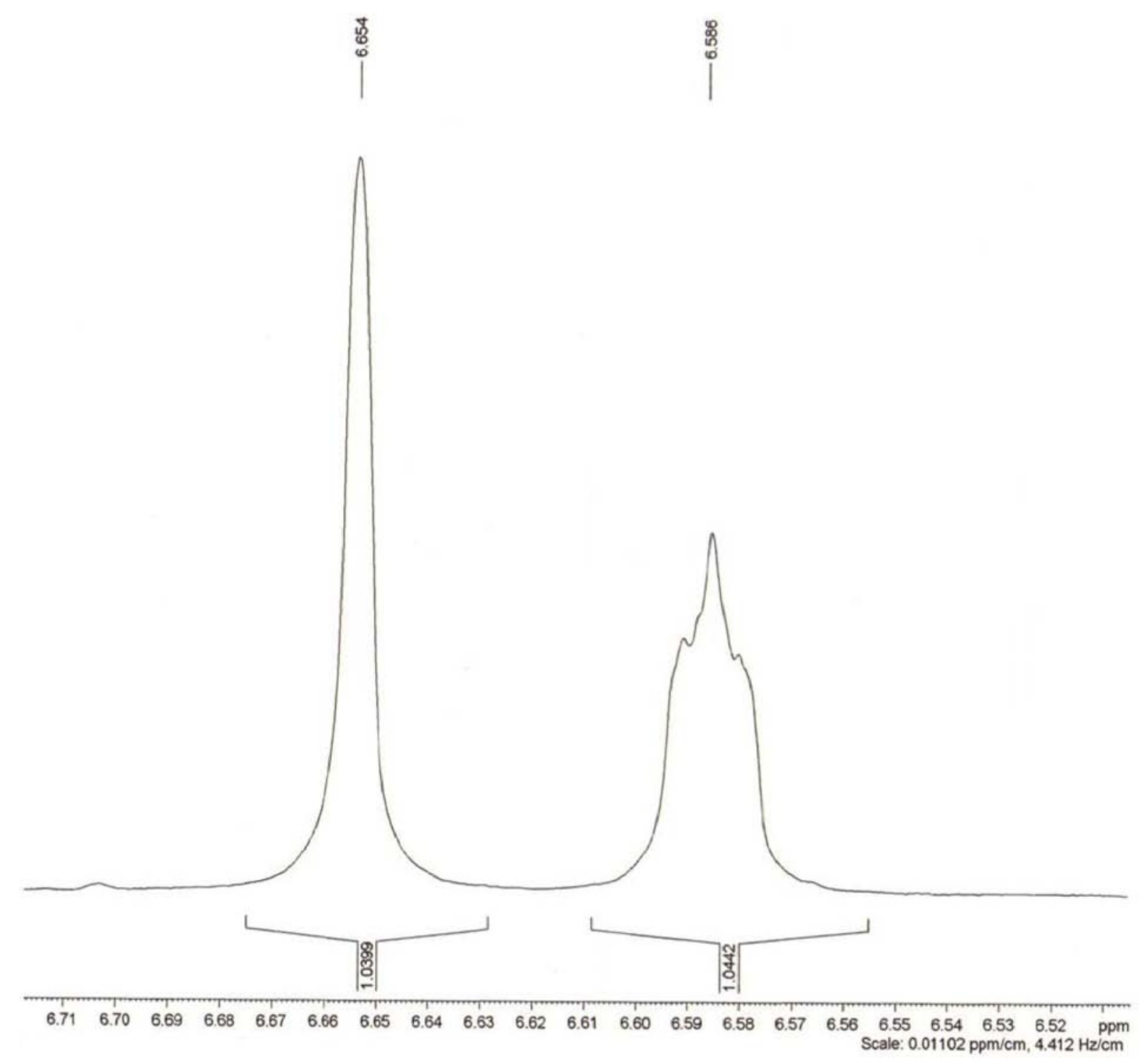

Figure S12. Expanded ${ }^{1} \mathrm{H}$ NMR spectrum of $\mathbf{4}$. 

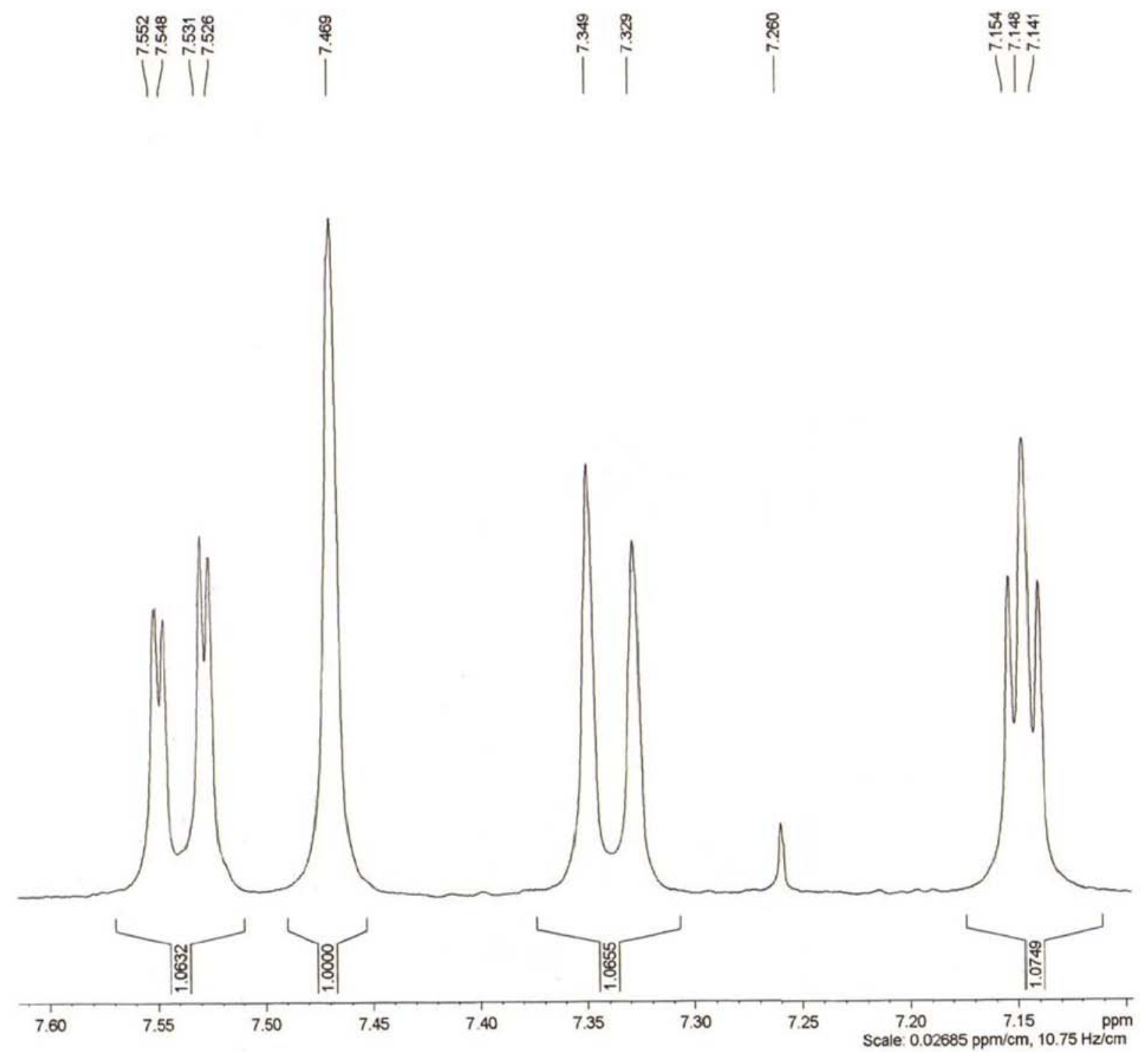

Figure S13. Expanded ${ }^{1} \mathrm{H}$ NMR spectrum of 4. 

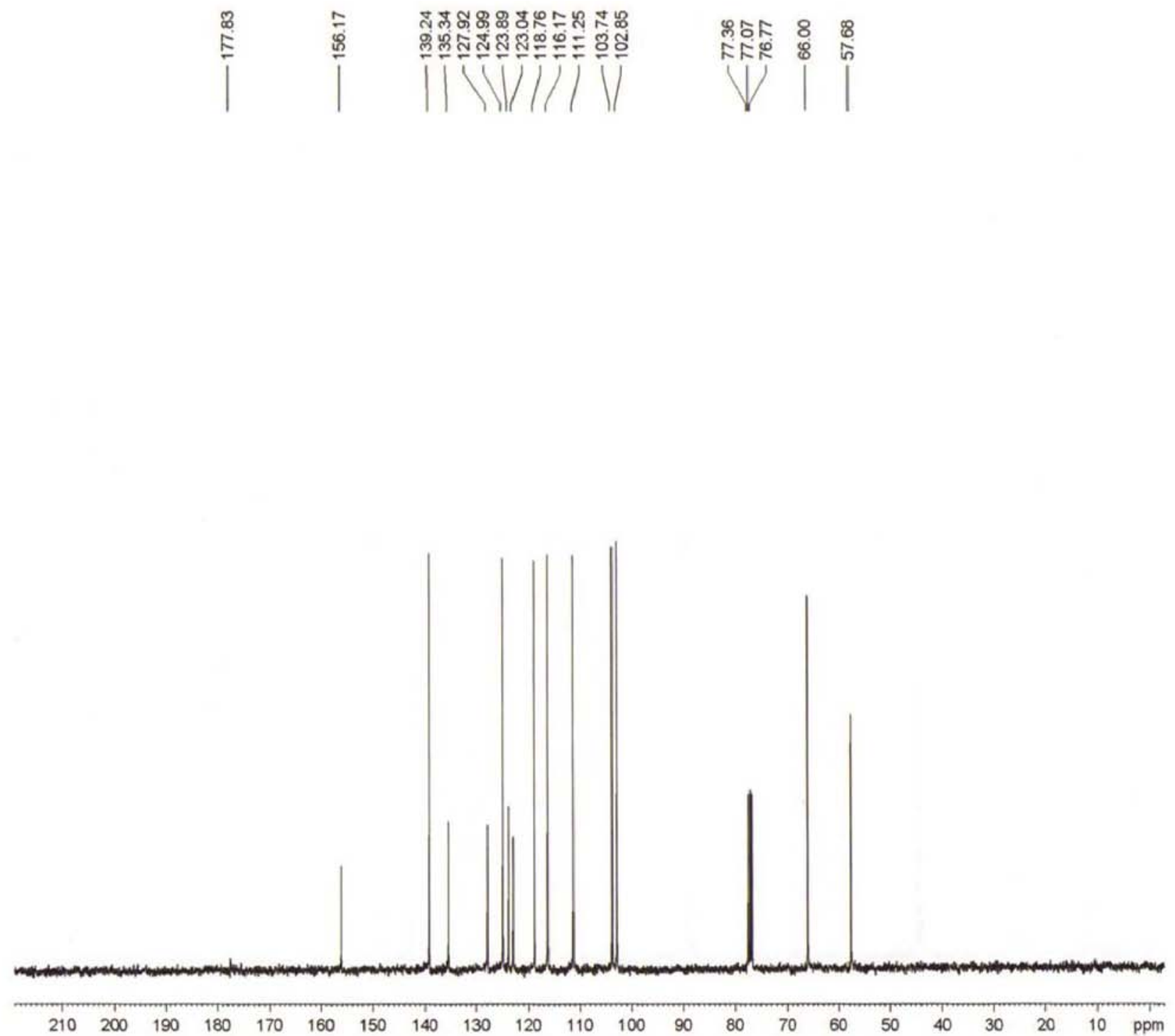

Figure S14. ${ }^{13} \mathrm{C}$ NMR spectrum of 4 . 


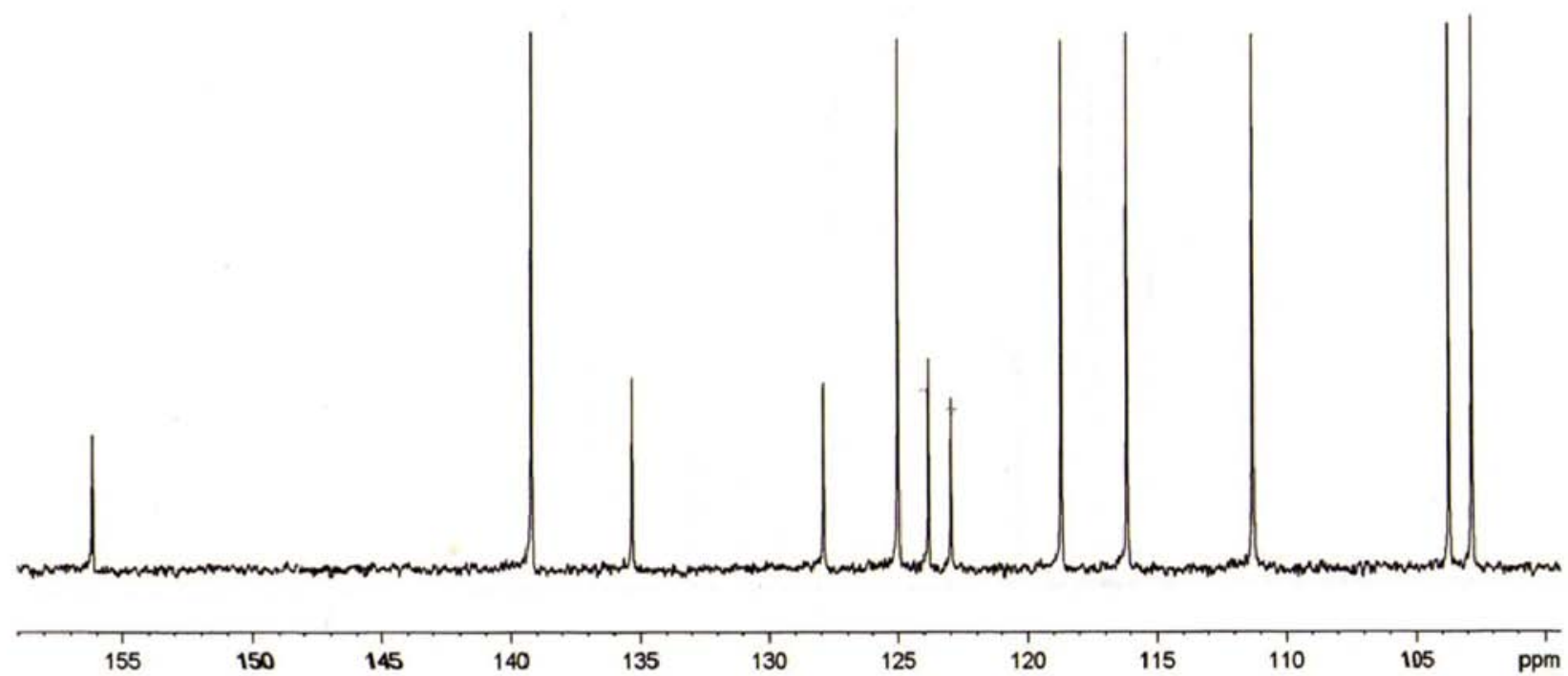

Figure S15. Expanded ${ }^{13} \mathrm{C}$ NMR spectrum of $\mathbf{4}$. 


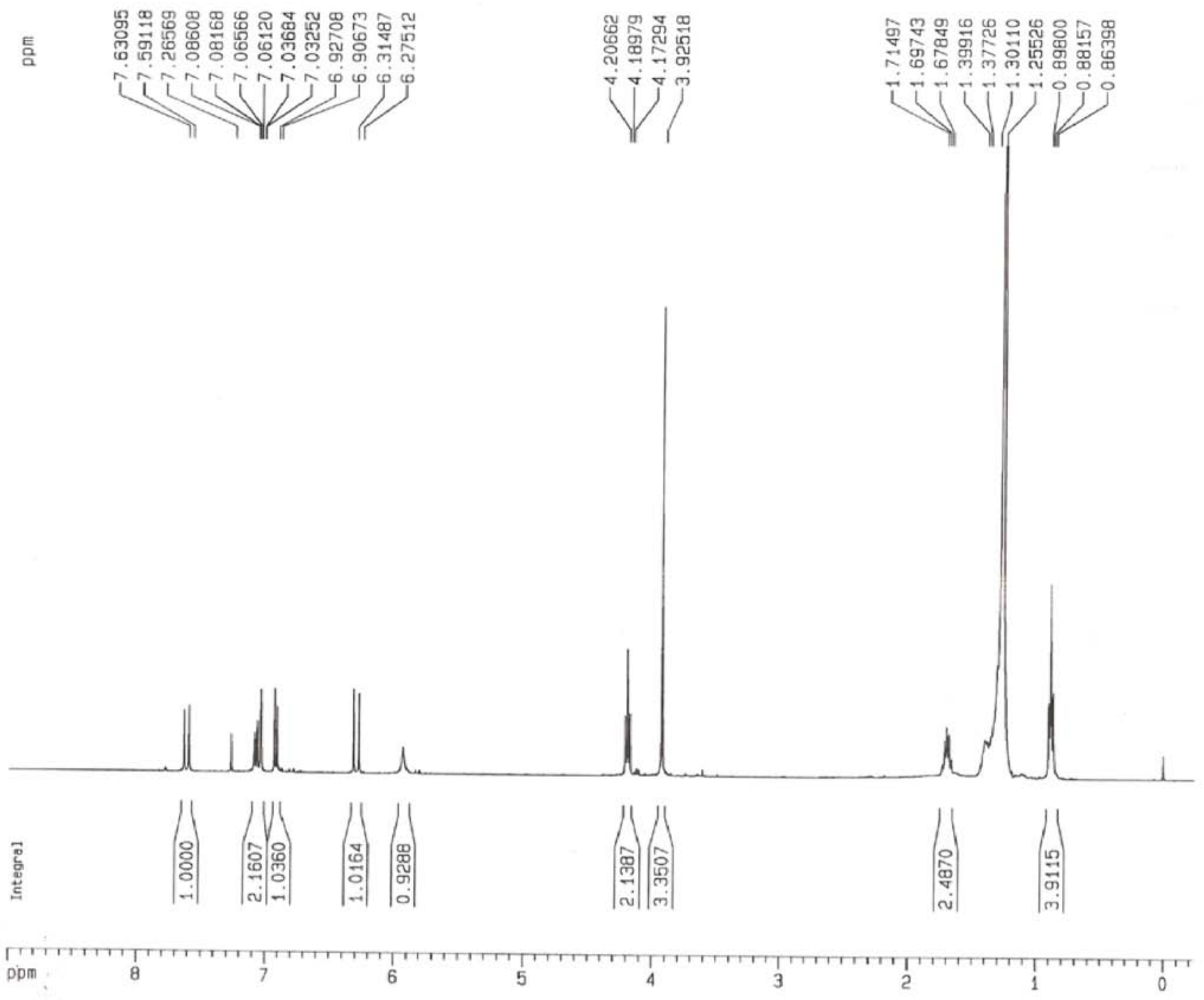

Figure S16. ${ }^{1} \mathrm{H}$ NMR spectrum of 5 . 

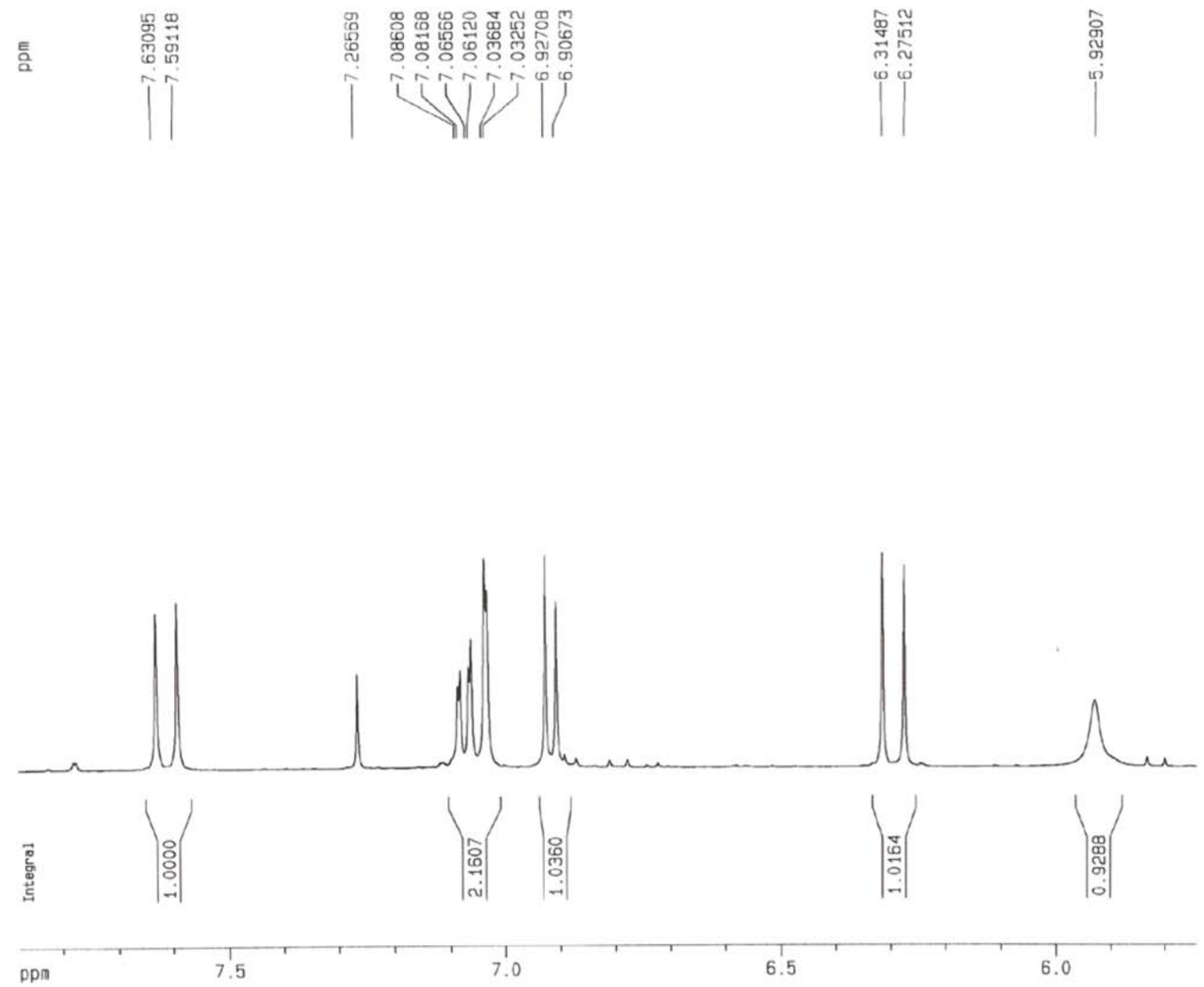

Figure S17. Expanded ${ }^{1} \mathrm{H}$ NMR spectrum of 5. 

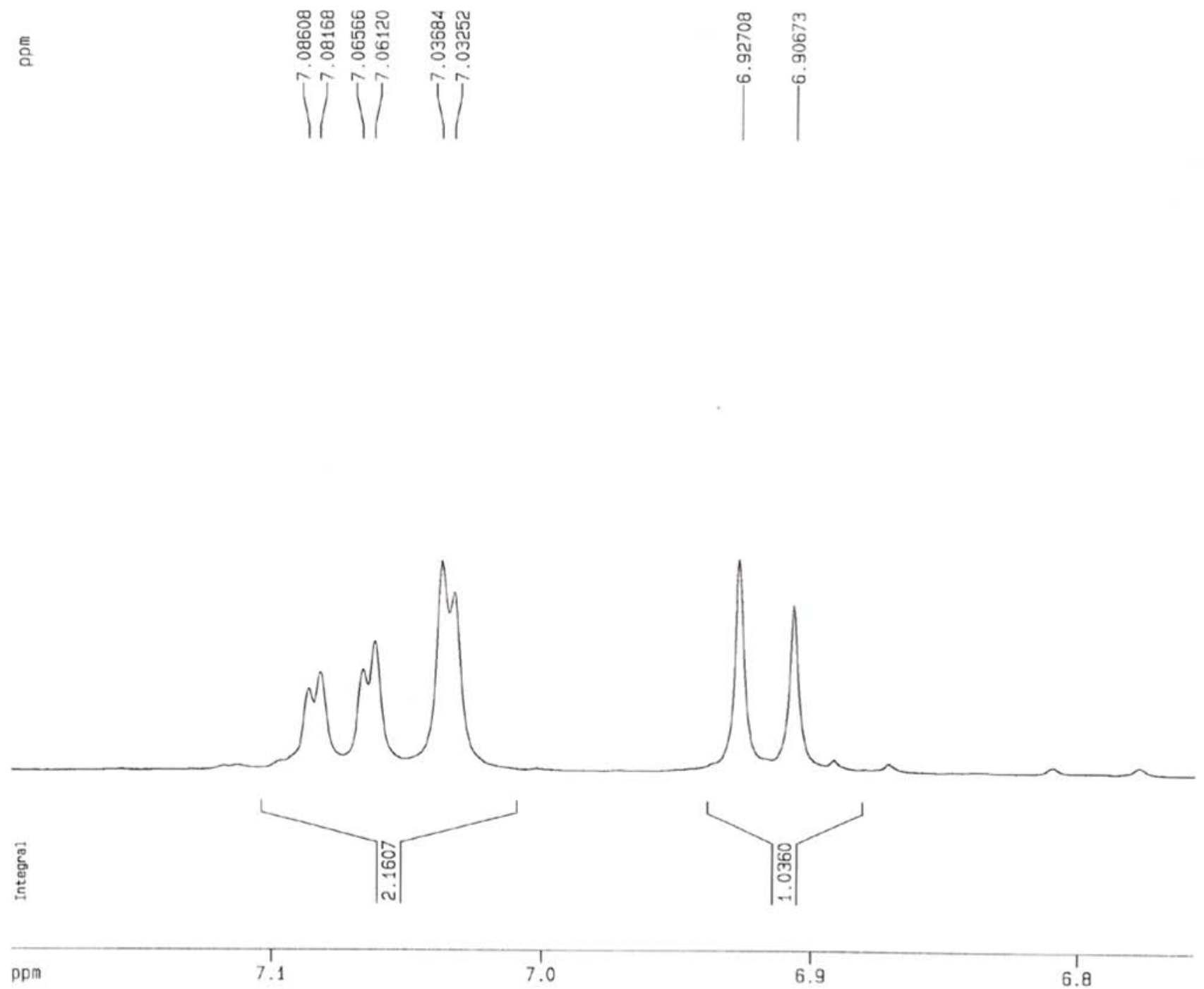

Figure S18. Expanded ${ }^{1} \mathrm{H}$ NMR spectrum of $\mathbf{5}$. 

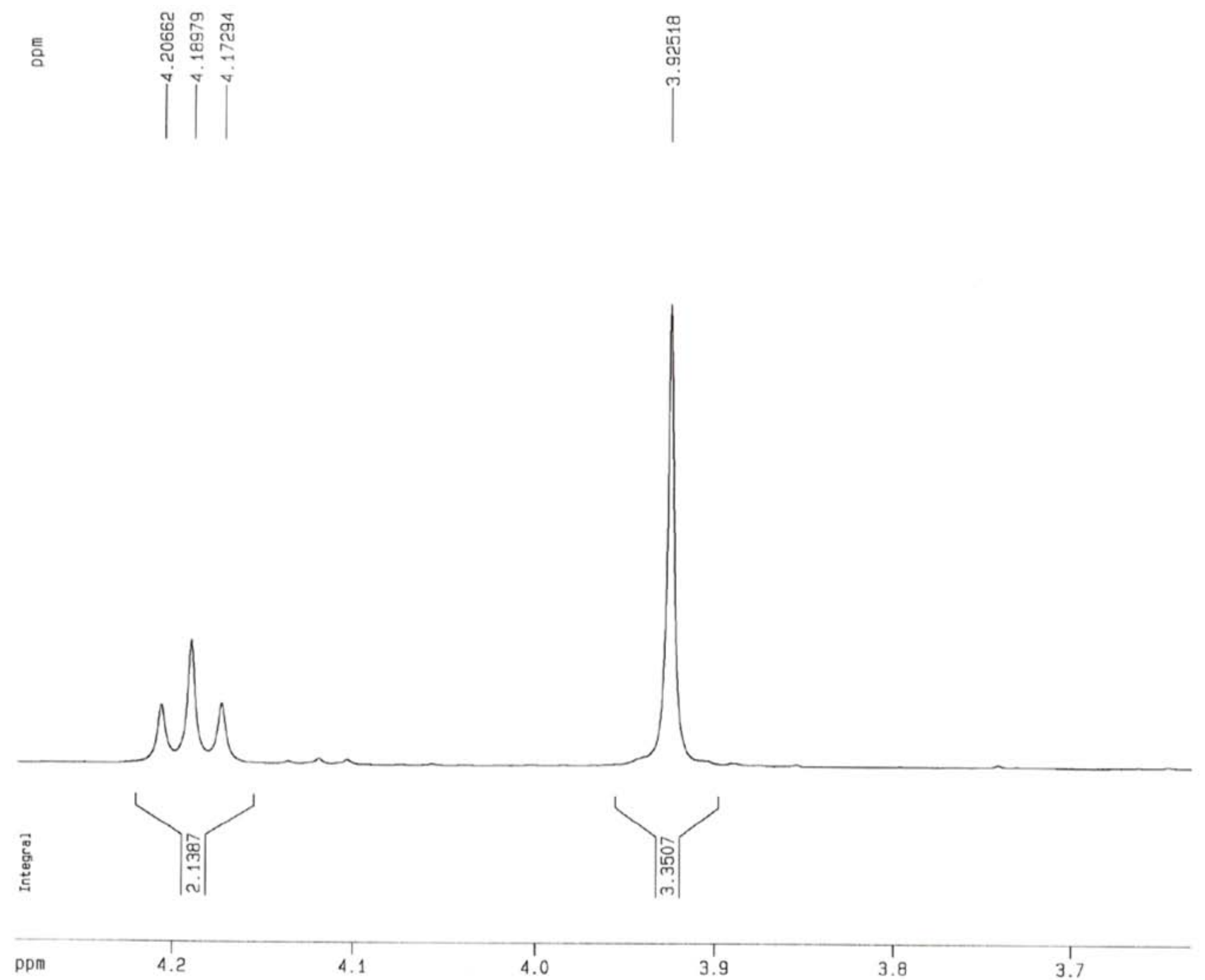

Figure S19. Expanded ${ }^{1} \mathrm{H}$ NMR spectrum of $\mathbf{5}$. 

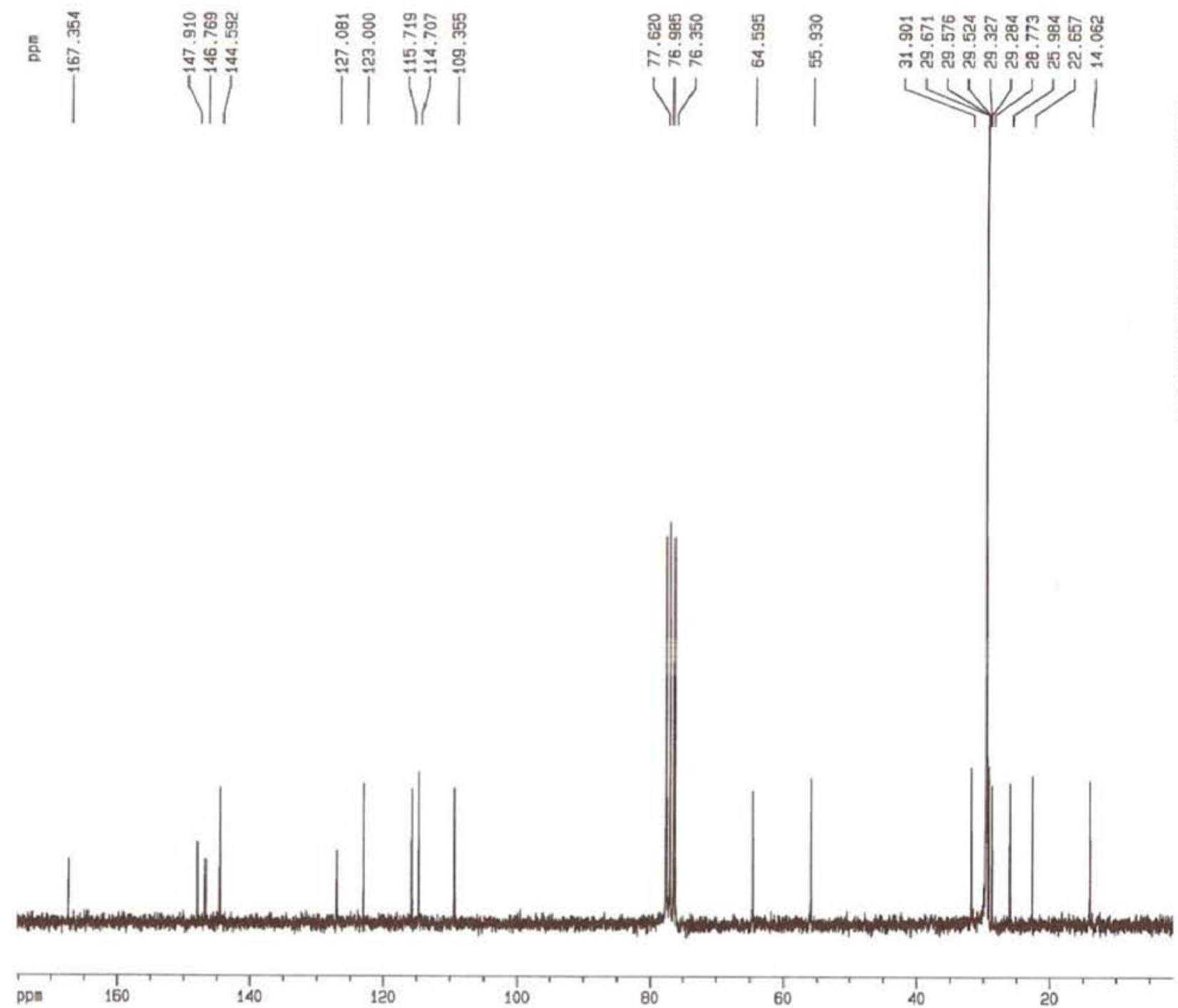

Figure S20. Expanded ${ }^{1} \mathrm{H}$ NMR spectrum of $\mathbf{5}$. 

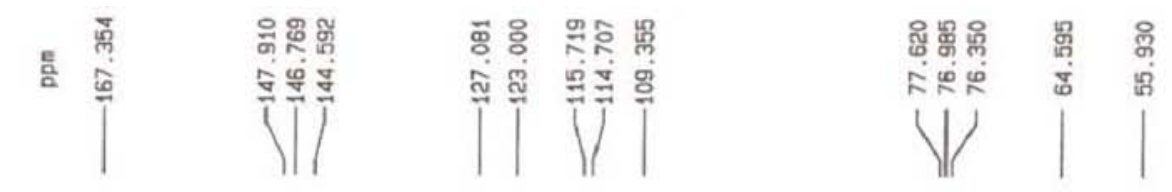

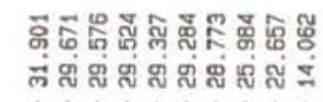

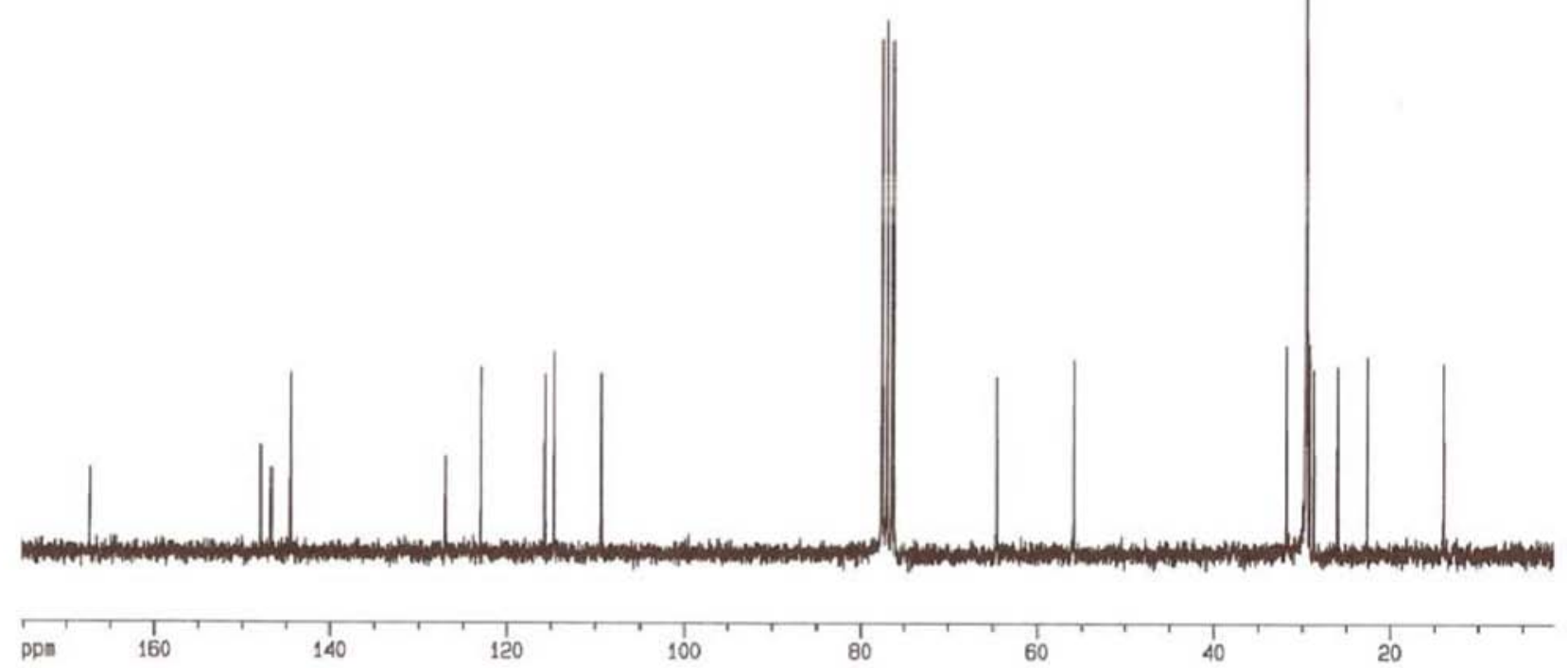

Figure S21. ${ }^{13} \mathrm{C}$ NMR spectrum of 5 . 


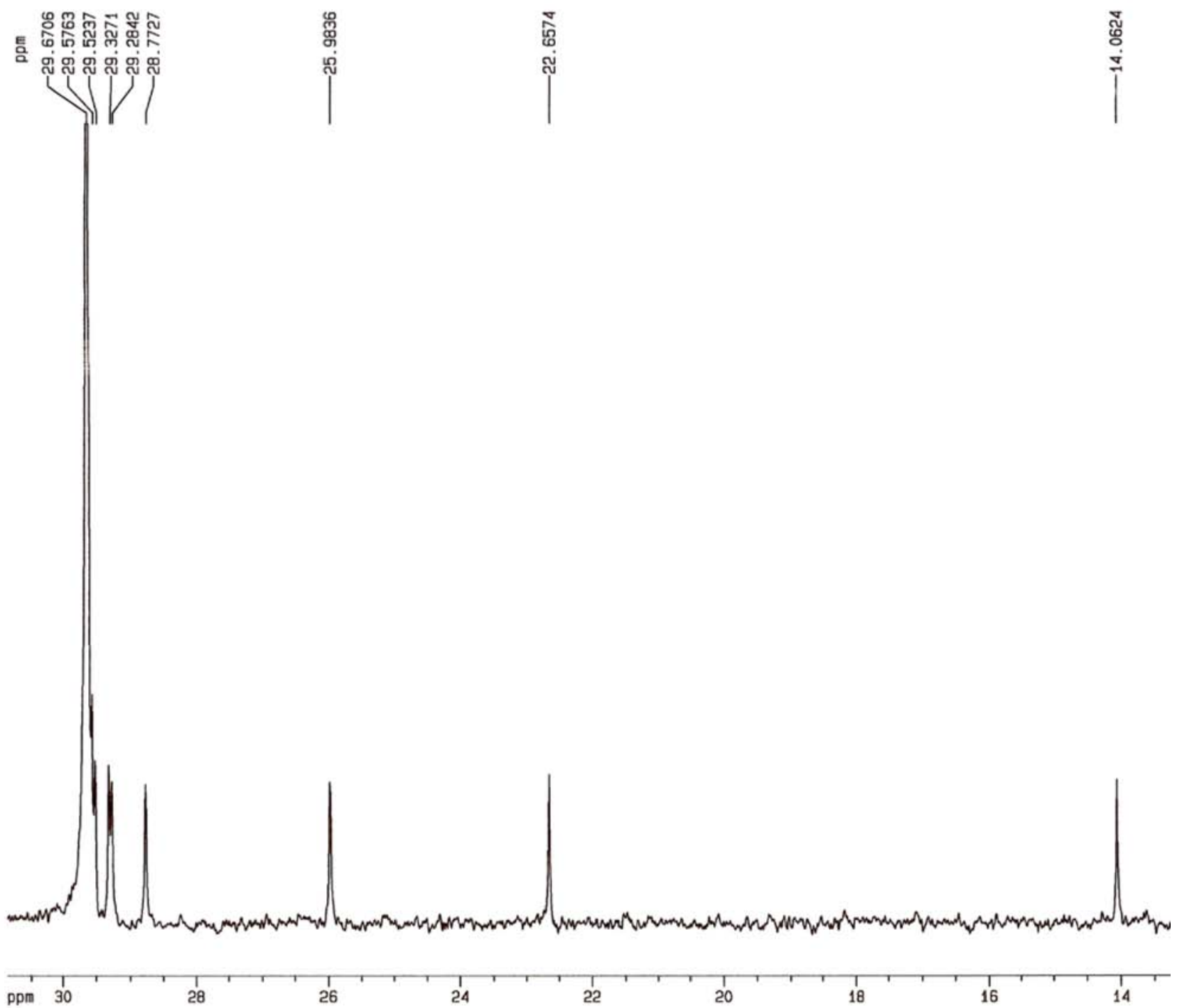

Figure S22. Expanded ${ }^{13} \mathrm{C}$ NMR spectrum of $\mathbf{5}$. 